\title{
Experimental determination of the oral bioavailability and bioaccessibility of lead particles
}

\author{
Elise Deshommes ${ }^{1}$, Robert Tardif ${ }^{2}$, Marc Edwards $^{3}$, Sébastien Sauvé ${ }^{4^{*}}$ and Michèle Prévost ${ }^{1}$
}

\begin{abstract}
In vivo estimations of Pb particle bioavailability are costly and variable, because of the nature of animal assays. The most feasible alternative for increasing the number of investigations carried out on $\mathrm{Pb}$ particle bioavailability is in vitro testing. This testing method requires calibration using in vivo data on an adapted animal model, so that the results will be valid for childhood exposure assessment. Also, the test results must be reproducible within and between laboratories. The Relative Bioaccessibility Leaching Procedure, which is calibrated with in vivo data on soils, presents the highest degree of validation and simplicity. This method could be applied to Pb particles, including those in paint and dust, and those in drinking water systems, which although relevant, have been poorly investigated up to now for childhood exposure assessment.
\end{abstract}

Keywords: Oral bioavailability, Bioaccessibility, Lead [Pb] particles, In vivo tests, In vitro tests

\section{Review}

\section{Introduction}

Lead $[\mathrm{Pb}]$ is hazardous to humans, and is of particular concern for fetuses, infants, children, and women of childbearing age $[1,2]$. Knowledge of $\mathrm{Pb}$ toxicity has progressed significantly since the 1970s. Initially considered toxic only at blood lead levels [BLLs] over $60 \mu \mathrm{g} / \mathrm{dL}$, it is now considered to have no definable threshold below which "no harmful effect" can be determined [3]. Early studies demonstrate the immediate and long-term effects of low $\mathrm{Pb}$ level exposure during childhood, such as neurobehavioral and neurodevelopmental deficiencies, and effects on growth, hearing, and blood pressure [3,4]. $\mathrm{Pb}$ uptake may reduce the intelligence quotient [IQ] of infants and children, and affect some brain responses, even at low BLLs. Recently, the effect on IQ has been shown to be even stronger at low BLLs, since decrements in IQ were more dramatic between BLLs categories $<5 \mu \mathrm{g} / \mathrm{dL}$ and $5-9.9 \mu \mathrm{g} / \mathrm{dL}$ than between categories $5-9.9 \mu \mathrm{g} / \mathrm{dL}$ and $\geq 10 \mu \mathrm{g} / \mathrm{dL}$, which has led to a reconsideration of the $10 \mu \mathrm{g} / \mathrm{dL}$ health advisory level [5-8]. Indeed, the European Food and Safety Agency (EFSA) has set the $95^{\text {th }}$ percentile lower confidence limit of the benchmark dose [BMD] of an incremental 1\%

\footnotetext{
* Correspondence: sebastien.sauve@umontreal.ca

${ }^{4}$ Department of Chemistry, Université de Montréal, 2900, Édouard-Montpetit, Montréal, QC H3C 3A7, Canada

Full list of author information is available at the end of the article
}

risk (BMDL01) at $1.2 \mu \mathrm{g} \mathrm{Pb} / \mathrm{dL}$ as a reference point when assessing the risk of intellectual deficits in children measured by the Full Scale IQ score [9]. Also, the EU Risk Assessment Report states that $\mathrm{Pb}$ exposure effects cannot be measured reliably at BLLs $<5 \mu \mathrm{g} / \mathrm{dL}$, due to the limited precision of methods of behavioral testing and $\mathrm{Pb}$ quantitation in blood [10]. Considering the neurocognitive and neurophysiological effects observed at low BLLs, a new reference level of $5 \mu \mathrm{g} / \mathrm{dL}$ was recently set by the $\mathrm{CDC}$, and will be revised downwards every 4 years [11].

Early studies on the health impacts on children led to public policies to remove $\mathrm{Pb}$ sources from food and leaded gasoline, resulting in the steady decline of BLLs in recent years [3,12-15]. Remedial actions have also been taken to decrease $\mathrm{Pb}$ levels in the soil and dust of $\mathrm{Pb}$-contaminated sites, although decreasing these levels may not always result in lower BLLs in children [14-17]. Lead paint is a common cause of clinical $\mathrm{Pb}$ poisoning, and remains a strong contributor to childhood exposure, as it is still present in houses built before 1978 in the United States; its abatement cost is estimated in the billions of dollars $[3,14,15]$. Now, as BLL guidelines become more stringent, the relative contribution of tap water to total $\mathrm{Pb}$ exposure may become highly significant [18-21]. Lanphear et al. report that $\mathrm{Pb}$ occurrence in water $>5 \mu \mathrm{g} / \mathrm{L}$ after $1 \mathrm{~min}$ of flushing increases the BLLs of children aged 6-24 months by $1.02 \mu \mathrm{g} / \mathrm{dL}$, 
contributing to about $20.4 \%$ of the total BLL [22]. Recently, abnormal BLLs in young children have been associated with elevated $\mathrm{Pb}$ concentrations in drinking water, particulate $\mathrm{Pb}$ representing a significant fraction of this [23-26]. However, because of its sporadic occurrence, exposure to particulate $\mathrm{Pb}$ in drinking water is especially difficult to characterize [27]. Most regulatory and research efforts have assumed that soluble $\mathrm{Pb}$ is the predominant form of exposure. Interest in particulate $\mathrm{Pb}$ is now growing, because of its potential contribution to chronic and acute exposure [27-29]. The most direct approach to assessing the contribution of various $\mathrm{Pb}$ sources to human exposure is to conduct epidemiological studies or in vivo studies. Numerous epidemiological studies of particulate $\mathrm{Pb}$ exposure from various media (i.e. air, soil, paint, and dust) have been reviewed [14,15,30,31]. Some of these revealed a significant relationship between environmental $\mathrm{Pb}$ levels and BLLs, and a decrease in BLLs after remediating $\mathrm{Pb}$ sources, providing direct measurements of exposure and its impacts on body burden. However, they are challenging to carry out because of cost, the variability of exposure among the population studied, and BLL evolution since exposure [32].

In vivo experiments are much simpler to plan and perform than epidemiological studies. Key parameters can be controlled, such as exposure levels and conditions, and the relationships between exposure levels and levels of $\mathrm{Pb}$ absorbed by the in vivo specimen tested can be quantified. However, the measurements are indirect, based on animal models, and require extrapolation to human exposure conditions. A primary outcome of in vivo studies of oral $\mathrm{Pb}$ exposure is the oral bioavailability of $\mathrm{Pb}$ occurring in both dissolved and particulate form. Several in vivo experiments have been performed, first with readily soluble $\mathrm{Pb}$ forms such as $\mathrm{Pb}$ acetate $[\mathrm{PbAc}]$, and then mostly with $\mathrm{Pb}$-contaminated soils. But comprehensive bioavailability experiments are long, expensive, demanding, and the use of animal models can raise ethical issues. Moreover, bioavailability results show significant variability, which is inherent to the use of animal models.

In vitro experiments are simpler, faster, cheaper, and highly reproducible, and do not raise ethical concerns, and therefore are best suited to test replication. However, they can only assess the bioaccessibility of $\mathrm{Pb}$, defined as the fraction of ingested $\mathrm{Pb}$ dissolved during the digestion process and available for absorption into the systemic circulation (bloodstream). Bioavailability is the fraction actually available and taken up by an organism, while bioaccessibility is an experimentally determined estimate of what is potentially bioavailable [33]. If well calibrated, an in vitro test can adequately predict in vivo results. A significant number of bioaccessibility studies have been conducted on $\mathrm{Pb}$ contaminated soils. However, the bioaccessibility of other sources of $\mathrm{Pb}$ particles to which infants/children can be exposed (paint, dust, drinking water particles, toys, and food) has not been thoroughly investigated. In vivo testing of these particulate forms can be limited by experimental constraints, which can be addressed using in vitro tests.

This review summarizes the information available on the bioavailability and bioaccessibility testing that have been proposed for estimating the oral bioavailability of $\mathrm{Pb}$ particles in children. Our objectives are to identify the strengths and weaknesses of these procedures, to highlight differences between them to support the interpretation of study conclusions, and, finally, to draw attention to gaps in the data on $\mathrm{Pb}$ particles that are relevant for childhood exposure assessment.

\section{Approaches to estimating $\mathrm{Pb}$ bioavailability}

Many definitions of bioavailability have been proposed for soil and sediments [33]. In this review, the term "oral bioavailability" refers to the amount of ingested $\mathrm{Pb}$ that reaches the systemic circulation and that is likely to accumulate in the body, including organs and bones. Historically, bioavailability has been determined in the laboratory using in vivo testing. In vivo testing to estimate $\mathrm{Pb}$ bioavailability must be carried out over an extended period to ensure that the metal is absorbed, retained, and excreted. The half-life of $\mathrm{Pb}$ is about 25 days in blood, 40 days in soft tissues, and 25 years in bones [34]. Early human experiments were conducted using $\mathrm{Pb}$ in the diet, $\mathrm{Pb}$ tracers, or $\mathrm{Pb}$ salts labeled with radioactive $\mathrm{Pb}^{203}$ [35-37]. A detailed review and critical evaluation of these studies is available in Mushak (1991) [30]. Such studies helped identify absorption mechanisms for soluble $\mathrm{Pb}$ and interactions with food, although there are still some uncertainties on the specific sites where $\mathrm{Pb}$ uptake actually takes place [30]. However, these results cannot be directly extrapolated to $\mathrm{Pb}$ particles in soil, dust, paint, or drinking water, because of potential matrix effects. A more recent study measured the bioavailability of soil borne $\mathrm{Pb}$ in human adults, and is the only study performed on humans with $\mathrm{Pb}$-contaminated soil [38]. The target population was adults, whose digestive absorption processes differ markedly from those of infants and children [30].

Most in vivo experiments have been conducted with young animals using various experimental designs. In general, several groups of animals are involved: a control group receiving a purified diet without any $\mathrm{Pb}$; a group receiving a $\mathrm{Pb}$ salt-based solution, such as $\mathrm{PbAc}$, either orally or intravenously (or both, if there are two groups), at different dosages representing the $\mathrm{Pb}$ dose range of the test materials; and, finally, a group administered with different doses of the test materials. Similar $\mathrm{Pb}$ doses from the test materials and from $\mathrm{PbAc}$ are necessary to ensure that the slopes of dose-response curves for both 
materials are comparable. Also, the range of the dosages applied usually includes low to high doses so that some degree of active transport (saturable) is represented in the blood compartment. $\mathrm{Pb}$ salts such as PbAc (soluble) are used as references to compare test materials and calculate bioavailability. Administering $\mathrm{Pb}$ salts intravenously allows the absolute bioavailability $[\mathrm{ABA}]$ - the fraction of $\mathrm{Pb}$ that enters the bloodstream (absorption fraction) - to be calculated (Equations 1-2). If $\mathrm{PbAc}$ is delivered orally, the relative bioavailability [RBA] - the bioavailability of the test material relative to that of $\mathrm{PbAc}$ - is calculated (Equation 3). The intravenous dosage for determining $\mathrm{ABA}$ is also used to set minimum and maximum BLLs for a range of doses and to better characterize $\mathrm{Pb}$ distribution in a steady state [39-41]. RBA is also called "oral bioavailability", but relative to an appropriate reference material (PbAc) [41,42]. RBA is more informative, because it takes the exposure matrix into account [43]. The ABA can be calculated, as opposed to measured, through intravenous injections, by multiplying the RBA by the $\mathrm{Pb}$ absorption fraction (ABA) of PbAc administered orally (Equation 4).

Oral ABA calculation:

$$
\begin{aligned}
& A B A_{T M}=\frac{I D M_{\text {oral } T M}}{I D M_{\text {iv } P b A c}} \times \frac{\text { Dose }_{\text {iv } P b A c}}{\text { Dose }_{\text {oral } T M}} . \\
& A B A_{P b A c}=\frac{I D M_{\text {oral } P b A c}}{I D M_{\text {iv PbAc }}} \times \frac{\text { Dose }_{i v} P b A c}{\text { Dose }_{\text {oral }} P b A c} .
\end{aligned}
$$

Oral RBA calculation:

$$
\begin{aligned}
R B A_{T M} & =\frac{A B A_{T M}}{A B A_{\text {oral } P b A c}} . \\
R B A_{T M} & =\frac{I D M_{\text {oral } T M}}{I D M_{\text {oral } P b A c}} \times \frac{\text { Dose }_{\text {oral } P b A c}}{\text { Dose }_{\text {oral } T M}} .
\end{aligned}
$$

Link between ABA and RBA:

$$
A B A_{T M}=A B A_{\text {oral }} P b A c \times R B A_{T M} .
$$

IDM - Internal Dose Metrics (BLL, Pb in tissues, etc.); iv - intravenous; TM - Test Material.

The internal dose metrics [IDM] measured during in vivo experiments can also vary. Several kinetic pools for $\mathrm{Pb}$ in the human body with varying rates of turnover, partly depending on the time elapsed since the administration of the $\mathrm{Pb}$ dose, affect bioavailability estimation. To address this, sequential blood samples can be collected during the experiment, as well as blood and tissue samples on the last day of the test. The tissue samples most frequently collected are from the liver, kidneys, and femurs. The amount of $\mathrm{Pb}$ stored in other parts of the body is considered to be small, in the order of $4 \%$ of total $\mathrm{Pb}$ measured in blood, bones, liver, and kidneys for short-term experiments [44]. So, RBA calculation can be based on $\mathrm{Pb}$ levels either in blood or in tissues: bloodbased RBA is calculated by measuring the ratio between BLL following test material ingestion and BLL following oral ingestion of PbAc for a similar dosage (Equation 3). This ratio is measured under presumed steady state conditions after repeated exposure, resulting in a stable BLL, or at various times during the experiment to monitor BLL evolution [44]. Similar ratios can be established for bones, kidneys, and liver on the last day of the experiment [45-47].

The most commonly used approach for evaluating bioavailability, and a comprehensive one, is based on monitoring BLLs over the course of the experiment for different dosages, as well as the $\mathrm{Pb}$ content in bones, kidneys, and liver at the end of the exposure period for different dosages. The "area-under-the-blood concentration versus time curve" [AUC] of BLL is then calculated for each $\mathrm{Pb}$ dose and test material (Figure 1). The AUC approach for BLL has the advantage of including the whole dose-response relationship of the BLL over the time of the experiment. However, the information it provides on the evolution of absorption over that period is poor [48]. AUC BLL (e.g. $\mu$ g $\times$ day/dL), bone Pb levels, or other kinds of IDM for Pb salt and test material are then fitted versus $\mathrm{Pb}$ dose. Identical absorbed doses of $\mathrm{Pb}$ delivered to target $\mathrm{Pb}$ pools are assumed to produce an equivalent IDM [40]. Bioavailability is determined by calculating the ratio of $\mathrm{Pb}$ test material dose and the $\mathrm{PbAc}$ dose that yields an identical IDM [40,49] (Figure 2). This calculation is equivalent to Equation 3, since the IDM for both the test material and the PbAc administered orally cancel each other out:

Oral RBA based on equivalent IDM:

$$
R B A_{T M}=\frac{\text { Dose }_{P b A c \text { oral producing equivalent IDM to } T M}}{\text { Dose }_{T M} \text { oral producing equivalent IDM to PbAc }} .
$$

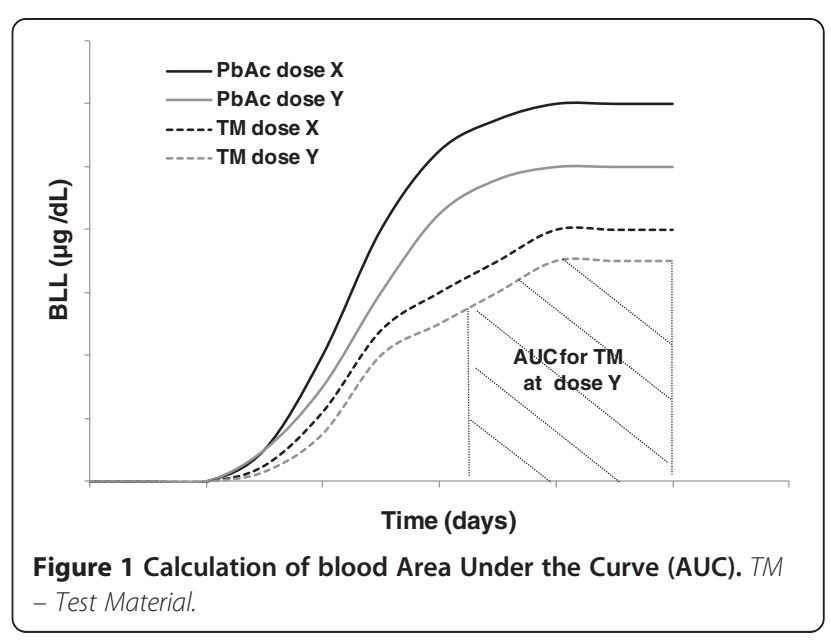




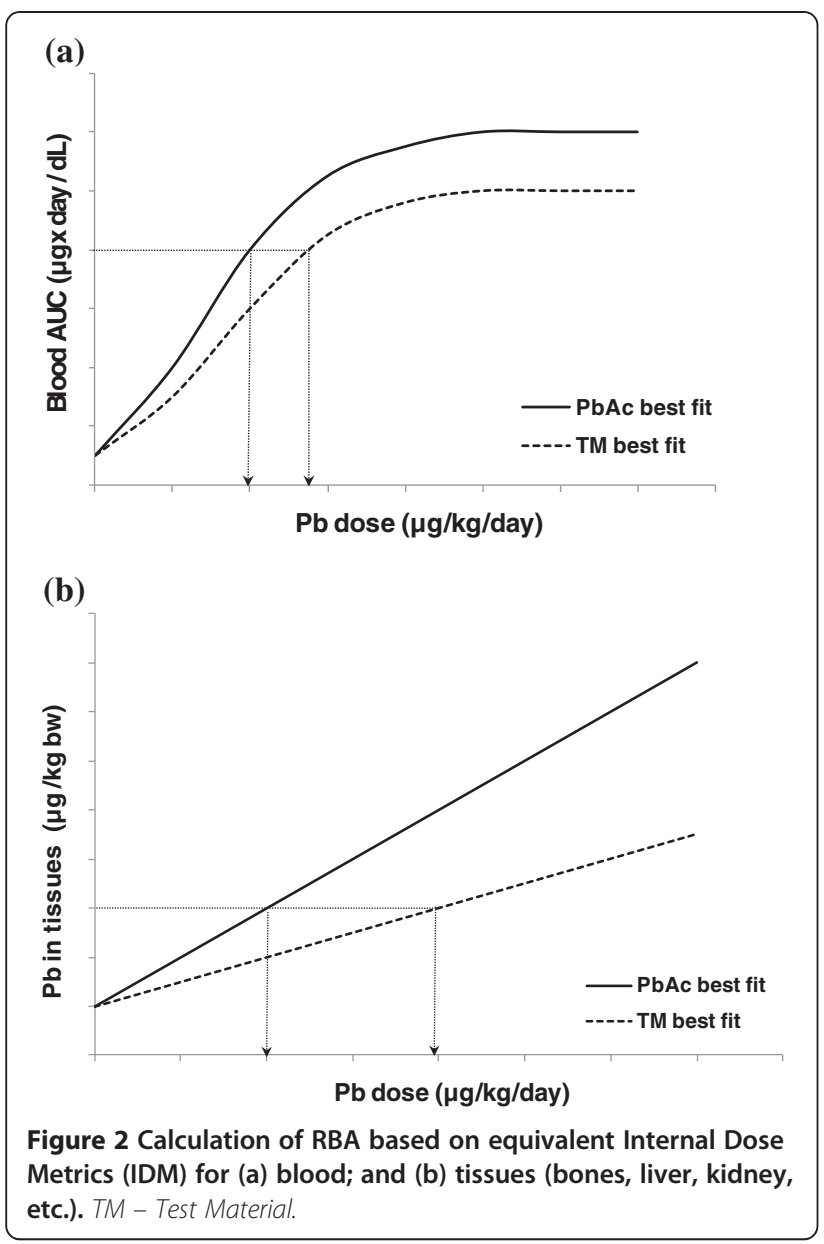

This approach requires finding the most suitable mathematical model for both the PbAc dose and the $\mathrm{Pb}$ test material dose IDMs. Indeed, an IDM per unit of absorbed $\mathrm{Pb}$ dose does not depend on the $\mathrm{Pb}$ source. The best fit for bone, liver, and kidney $\mathrm{Pb}$ levels is usually linear, whereas for BLL/AUC, which increases gradually and then reaches a plateau (steady state), the best fit is non linear and varies [42,49]. Doses of $\mathrm{Pb}$ test material and $\mathrm{Pb}$ salt producing the same IDM can be calculated from the best fitting equations, and the bioavailability ratio calculated for each endpoint studied (AUC, BLL, Pb in bones, etc.). The BLL/AUC used for this ratio is usually the point before the rate of uptake of $\mathrm{Pb}$ from the test material starts to decrease owing to increasing dosage [40]. The ratio can also be calculated for a range of doses that reflects currently estimated exposure. Finally, a point estimate can also be calculated, which combines the bioavailability related to each of the endpoints studied simultaneously, and is weighted according to its uncertainty. However no significant differences were shown between using only a BLL estimate or a point estimate based on multiple IDM $[42,49]$.
Another way to evaluate bioavailability is to complete a total mass balance. This method requires sequential BLL sampling, as well as total collection of urine and feces to recover all the excreted $\mathrm{Pb}$. $\mathrm{Pb}$ content in feces and urine is subtracted from total $\mathrm{Pb}$ intake, and provides an estimate of the body's net retention [37]. Urine samples represent the absorbed dose of $\mathrm{Pb}$ that is primarily excreted, whereas fecal samples provide the fraction of $\mathrm{Pb}$ that is unabsorbed [50]. When BLLs reach a steady-state with multiple dosing, bioavailability can be determined by calculating the ratio of total $\mathrm{Pb}$ in the urine plus total $\mathrm{Pb}$ retained in the body to total $\mathrm{Pb}$ recovered. Such results have limited value if the total net excretions are underestimated. However, this method is nearly non invasive for the test subject, and can provide information on $\mathrm{Pb}$ accumulation in the body after repeated exposure. This makes it useful for studies on $\mathrm{Pb}$ uptake and $\mathrm{Pb}$ distribution in the whole body [48].

The method for calculating the bioavailability and IDM on which it is based directly influences the bioavailability estimates. Understanding these differences is important when comparing results based on different methodologies. An RBA based on BLL is unlikely to provide the same results as global bioavailability based on the whole body's $\mathrm{Pb}$ uptake derived from a complete mass balance. If bioavailability is based on the blood AUC, the results will be influenced by the duration of the experiment and the timing of sampling. Furthermore, the interactions between $\mathrm{Pb}$ in soft tissues, bones, and blood determine the fractional absorption, and thus the bioavailability [51]. The timing of the sampling should be chosen carefully, considering the evolution of BLL over time and whether or not steady state is reached [52].

\section{Experimental factors influencing $\mathrm{Pb}$ bioavailability}

The in vivo experimental design parameters affecting the estimation of $\mathrm{Pb}$ bioavailability include: the animal model (species), its age, the addition of food, the duration of the experiment, and the dosage. The selection of these parameters and corresponding bioavailability results for published studies are summarized in Table 1 .

\section{Animal model}

A major factor affecting bioavailability estimation is the animal species used, and includes its age and its developmental stage. Intra-species differences in anatomy, feeding behavior, absorption rate, and digestion processes influence the results. As shown in Table 1, rats, piglets, and rabbits have been used to estimate $\mathrm{Pb}$ particle bioavailability. Pioneer studies used rodents and rabbits to determine bioavailability and the risk to infants/children $[39,44,45,54,55,71-74]$.

Although rodents and lagomorphs are widely used and well-known animal in vivo models, differences in their 
Table 1 In vivo experiments on $\mathrm{Pb}$ particles and bioavailability results (2 pages)

\begin{tabular}{|c|c|c|c|c|}
\hline REFERENCE & SPECIMEN & SUBSTRATE & $\begin{array}{l}\text { STATE, DURATION, } \\
\text { DOSE }\end{array}$ & RBA/ABA \\
\hline \multirow[t]{3}{*}{ Freeman et al. 1992 [45] } & \multirow[t]{3}{*}{ Rats (7-8 wk) } & \multirow[t]{3}{*}{ Mine wastes } & - Fed & • $12.1 \pm 3.6-26.8 \pm 4.8$ (blood RBA \%) \\
\hline & & & $\cdot 30 d$ & • 4.8 $\pm 1.9-13.3 \pm 2.2$ (bone RBA \%) \\
\hline & & & $\cdot 0.12-24 \mathrm{mg} \mathrm{Pb} / \mathrm{kg} \mathrm{bw} / \mathrm{d}$ & • 0.6 $\pm 3.1-13.6 \pm 3.1$ (liver RBA \%) \\
\hline \multirow[t]{3}{*}{ Dieter et al. 1993 [53] } & \multirow[t]{3}{*}{ Rats (6-7 wk) } & \multirow{3}{*}{$\begin{array}{l}\mathrm{Pb} \text { oxide, } \mathrm{Pb} \text { sulfide, } \\
\mathrm{Pb} \text { ore concentrate }\end{array}$} & - Fed & • $69-93$ (blood RBA \%, Pb oxide) \\
\hline & & & $\cdot 30 d$ & • ND-36 (blood RBA \%, Pb sulfide) \\
\hline & & & •0-100 ppm Pb & - ND-10 (blood RBA \%, Pb ore) \\
\hline \multirow[t]{3}{*}{ Freeman et al. 1993 [54] } & \multirow[t]{3}{*}{ Rats (7-8 wk) } & \multirow[t]{3}{*}{ Mine wastes } & - Fed & • $0.36 \pm 1.04-7.32 \pm 1.57$ (blood ABA \%) \\
\hline & & & $\cdot 30 \mathrm{~d}$ & • $0.51 \pm 0.15-2.25 \pm 0.23$ (bone ABA \%) \\
\hline & & & - 5 to $20 \mathrm{ppm} \mathrm{Pb}$ & \\
\hline \multirow[t]{3}{*}{ Ruby et al. 1993 [55] } & \multirow[t]{3}{*}{ Rabbits (12 wk) } & \multirow[t]{3}{*}{ Mine wastes } & - Fast & \multirow[t]{3}{*}{ - $9 \pm 4 \% \mathrm{~Pb}$ soluble in stomach } \\
\hline & & & $\cdot 0.5-36 \mathrm{~h}$ & \\
\hline & & & • 7.8 mg Pb/kg bw & \\
\hline \multirow[t]{3}{*}{ Freeman et al. 1994 [39] } & \multirow[t]{3}{*}{ Rats (7-8 wk) } & \multirow[t]{3}{*}{ Mine wastes } & - Fed & $\cdot 2.7 \pm 1.5$ (\% blood RBA) \\
\hline & & & $\cdot 30 \mathrm{~d}$ & • $0.40 \pm 0.16$ (\% bone RBA) \\
\hline & & & $\begin{array}{l}\cdot 0.12 \text { to } 24 \mathrm{mg} \mathrm{Pb} / \mathrm{kg} \mathrm{bw} / \\
\mathrm{d}\end{array}$ & $\cdot 0.55 \pm 0.68$ (\% liver RBA) \\
\hline \multirow[t]{3}{*}{ Schoof et al. 1995 [40] } & \multirow[t]{3}{*}{ Rats (4 wk) } & \multirow[t]{3}{*}{ Smelter soil } & - Fed & . 41 (\% blood RBA) \\
\hline & & & $\cdot 31 \mathrm{~d}$ & . 20 (\% blood ABA) \\
\hline & & & • $0.11-3.4 \mathrm{mg} \mathrm{Pb} / \mathrm{kg} \mathrm{bw/d}$ & \\
\hline \multirow[t]{3}{*}{ Freeman et al. 1996 [44] } & \multirow[t]{3}{*}{ Rats $(\sim 4$ wk) } & \multirow[t]{3}{*}{ Soil, Pb sulfide } & - Fed & • 0.8-8.7 (soil, \% RBA) \\
\hline & & & $.44 d$ & • 1.2-5 (Pb sulfide,\% RBA) \\
\hline & & & • 17.6-127 ppm & \\
\hline \multirow[t]{3}{*}{ Lorenzana et al. 1996 [56] } & \multirow[t]{3}{*}{ Swine (40-50 d) } & \multirow[t]{3}{*}{ Tacoma smelter soil \& slag } & - Fast (small dough) & \multirow{3}{*}{$\begin{array}{l}\text { - Mean } \mathrm{ABA}^{\S}\left(\%, \mathrm{PbAc}_{\mathrm{iv}}\right): 10 \text { (soil), } \\
4 \text { (slag) }\end{array}$} \\
\hline & & & $\cdot 0-7 d$ & \\
\hline & & & $\begin{array}{l}\cdot 34-567 \mu \mathrm{g} \mathrm{Pb} / \mathrm{kg} \text { bw } \\
\text { (single dose) }\end{array}$ & \\
\hline \multirow[t]{3}{*}{ Casteel et al. 1997 [49] } & \multirow[t]{3}{*}{ Swine (8-9 kg) } & Berm and residential soils & - Fast (small dough) & • 74-75 (point estimate RBA $\%^{\ddagger}$ ) \\
\hline & & & $\cdot 15 \mathrm{~d}$ & \\
\hline & & & • $71-732 \mu \mathrm{g} \mathrm{Pb} / \mathrm{kg}$ bw/d & \\
\hline Casteel et al. 1997-1998 ${ }^{\#}$ & Swine & $\begin{array}{l}\text { Joplin smelter soil treated or } \\
\text { not with } 1 \% \text { phosphate }\end{array}$ & & $\begin{array}{l}\text { - Point estimate RBA (\%): 59-67 } \\
\text { (not treated) to 38-45 (treated 1\% } \\
\text { phosphate) }\end{array}$ \\
\hline Maddaloni et al. 1998 [38] & Humans (21-40 & Bunker Hill residential soil & - Fast \& Fed & - Fasting state: $26.2 \pm 8.1$ (\% ABA) \\
\hline & & & $\cdot 30 \mathrm{~h}$ & $\begin{array}{l}\text { - With breakfast meal: } 2.52 \pm 1.7 \\
(\% \text { ABA) }\end{array}$ \\
\hline & & & • 250 mg Pb/70 kg bw & \\
\hline Ellickson et al. 2001 [57] & Rats $(0.18-0.2 \mathrm{~kg})$ & SRM 2710 Montana soil & - Fast & • $0.4-0.9$ (\% RBA) \\
\hline & & & $\cdot 3 d$ & \\
\hline & & & - 7-8 mg Pb (single dose) & \\
\hline Brown et al. 2003 [58] & Rats (3-4 wk) & Urban soil treated with & - Fed & - RBA not calculated in \% \\
\hline & & biosolids ( $n=9$ ) & $\cdot 35 d$ & \\
\hline & & & . $71-125$ mg Pb/kg diet & \\
\hline
\end{tabular}


Table 1 In vivo experiments on $\mathrm{Pb}$ particles and bioavailability results ( 2 pages) (Continued)

\begin{tabular}{|c|c|c|c|c|}
\hline \multirow[t]{4}{*}{$\begin{array}{l}\text { Hettiarachchi et al. } \\
2003[59]\end{array}$} & \multirow[t]{4}{*}{ Rats (12 wk) } & \multirow{4}{*}{$\begin{array}{l}\text { Joplin soil treated or not with } \\
\text { Mn, phosphate, or CRYP } \\
(n=15)\end{array}$} & - Fed. $21 \mathrm{~d}$ & $\begin{array}{l}\text { - Blood RBA\%: } 34 \text { (not treated); } \\
\text { 19-33 (treated) }\end{array}$ \\
\hline & & & \multirow[t]{3}{*}{-1-6 mg Pb/kg bw/d } & $\begin{array}{l}\text { - Kidney RBA\%: } 48 \text { (not treated); } \\
\text { 19-39 (treated) }\end{array}$ \\
\hline & & & & $\begin{array}{l}\text { - Liver RBA\%: } 27 \text { (not treated); 19-21 } \\
\text { (treated) }\end{array}$ \\
\hline & & & & $\begin{array}{l}\text { - Bone RBA\%: } 34 \text { (not treated); 20-24 } \\
\text { (treated) }\end{array}$ \\
\hline \multirow[t]{3}{*}{ USEPA 2004, $2009[60,61]$} & \multirow[t]{3}{*}{ Juvenile swine } & \multirow[t]{3}{*}{2 Omaha smelter soils } & - Fast (small dough) & \multirow[t]{3}{*}{ • 83 \& 96 (point estimate RBA \%) } \\
\hline & & & $\cdot 15 d$ & \\
\hline & & & • 75-675 $\mu \mathrm{g} \mathrm{Pb/kg} \mathrm{bw/d}$ & \\
\hline \multirow[t]{3}{*}{ Casteel et al. 2006 [42] } & \multirow[t]{3}{*}{ Swine (5-6 wk) } & \multirow[t]{3}{*}{19 soil or soil-like materials ${ }^{\dagger}$} & - Fast (small dough) & \multirow[t]{3}{*}{ - 1-105 (point estimate RBA \%) } \\
\hline & & & $\cdot 15 \mathrm{~d}$ & \\
\hline & & & • 75-675 $\mu \mathrm{g} \mathrm{Pb/kg} \mathrm{bw/d}$ & \\
\hline \multirow[t]{3}{*}{ Marschner et al. 2006 [62] } & \multirow[t]{3}{*}{ Swine $(70 \mathrm{~d})$} & \multirow[t]{3}{*}{5 soils } & $\begin{array}{l}\text { - Semi-fed (milk powder } \\
\text { after } 5 \mathrm{~h} \text { fast) }\end{array}$ & \multirow[t]{3}{*}{ • 17-63 (RBA \%) } \\
\hline & & & $\cdot 28 d$ & \\
\hline & & & • 0.1-3.2 mg Pb/kg bw/d & \\
\hline \multirow{3}{*}{$\begin{array}{l}\text { MSE Technology } \\
\text { Application } 2006 \text { [63] }\end{array}$} & \multirow[t]{3}{*}{ Swine (5-6 wk) } & \multirow[t]{3}{*}{ Smelter soil HER-2930 } & - Fast (small dough) & \multirow[t]{3}{*}{ • 82 (point estimate RBA \%) } \\
\hline & & & $\cdot 15 \mathrm{~d}$ & \\
\hline & & & • 77-686 $\mu \mathrm{g} \mathrm{Pb/kg} \mathrm{bw/d}$ & \\
\hline \multirow[t]{3}{*}{ Smith Jr. et al. 2008 [46] } & \multirow{3}{*}{$\begin{array}{l}\text { Rats }(\sim 21 \mathrm{~d}) \\
\text { Micropigs }(\sim 30 \mathrm{~d})\end{array}$} & \multirow[t]{3}{*}{2 smelter soils } & - Fed & - Rats RBA \%: 88 (blood), 62 (bone) \\
\hline & & & $\cdot 30 d$ & \multirow[t]{2}{*}{$\begin{array}{l}\text { - Micropigs RBA \%: } 81 \text { (blood), } \\
68 \text { (bone) }\end{array}$} \\
\hline & & & - $50 \mu \mathrm{g} \mathrm{Pb} / \mathrm{g}$ diet & \\
\hline \multirow[t]{3}{*}{ Smith Jr. et al. 2008 [47] } & \multirow[t]{3}{*}{ Rats $(\sim 21 \mathrm{~d})$} & \multirow[t]{3}{*}{5 soils } & - Fed & • $85 \pm 48$ (blood RBA \%) \\
\hline & & & $\cdot 35 \mathrm{~d}$ & \multirow[t]{2}{*}{ • $91 \pm 12$ (bone RBA \%) } \\
\hline & & & • 6.8-150 $\mu \mathrm{g} \mathrm{Pb/g} \mathrm{diet}$ & \\
\hline \multirow[t]{3}{*}{ Bannon et al. 2009 [64] } & Juvenile swine & 8 small arms range soils & - Fast (small dough) & • $108 \pm 18$ (point estimate RBA \%) \\
\hline & & & $\cdot 15 d$ & \\
\hline & & & - 75-675 $\mu \mathrm{g} \mathrm{Pb} / \mathrm{kg}$ bw/d & \\
\hline Caboche 2009 Denys et al. & Swine (28d) & 15 mining and smelting soils & - Fast (small dough) & • 6-100 (kidney RBA \%) \\
\hline $2012[05,06]$ & & & - $14 d$ & • 8-100 (urine RBA \%) \\
\hline & & & $\cdot<1$ to $8 \mathrm{mg} \mathrm{Pb} / \mathrm{kg} \mathrm{bw/d}$ & • 9-100 (bone RBA \%) \\
\hline & & & & • 10-85 (liver RBA \%) \\
\hline Juhasz et al. 2009 [67] & Swine (6-8 wk) & 5 incinerator and urban soils & - Fast & 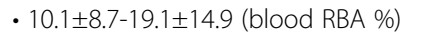 \\
\hline & & & $\cdot 5 d$ & \\
\hline & & & $\begin{array}{l}\cdot 0.1-1.2 \mathrm{mg} \mathrm{Pb} / \mathrm{kg} \mathrm{bw} \\
\text { (single dose) }\end{array}$ & \\
\hline Smith et al. 2011 [68] & Adult mice & $12 \mathrm{~Pb}$ impacted soils from & - Fast & • 10 $\pm 2.8-89 \pm 15.3$ (blood RBA \%) \\
\hline & & various sources & . $48 \mathrm{~h}$ & \\
\hline & & & $\begin{array}{l}\cdot 0.1-1.7 \mathrm{mg} \mathrm{Pb} \text { (single } \\
\text { dose) }\end{array}$ & \\
\hline
\end{tabular}


digestive systems compared to the human prevent direct extrapolation to the $\mathrm{Pb}$ exposure of human children. First, rodent stomachs have a smaller glandular region than human stomachs, and consequently less surface area for parietal cells secreting acid [48]. This results in a higher stomach $\mathrm{pH}$ of 3.9 and 3.2 in the fasting and fed states respectively [75]. In contrast, rabbits present a relatively low $\mathrm{pH}$ of 1.6 in the fed state, which is significantly lower than that of humans [76]. Also, the surface area of the small intestine of a rat is about one-fifth the size a human one, which implies decreased $\mathrm{Pb}$ bioavailability, since some absorption mechanisms in the small intestine are surface area-dependent [48]. Another significant difference is that the rat's small intestine is mature at weaning, unlike that of the human newborn, and its $\mathrm{Ca}$ absorption capacity decreases rapidly within 30 days [48]. This results in a drastic decrease in the rat's $\mathrm{Pb}$ absorption rate, from about $80 \%$ between 0 and 30 days to about $50 \%$ between 1-2 weeks and 6-8 weeks $[30,51]$. Several in vivo studies listed in Table 1 have used rats aged 4 weeks and 6-7 weeks [39,40,44,45,54,57], which may have been too old to be representative of the high $\mathrm{Pb}$ absorption rates found in children 0-6 years old [52]. Differences in the soils tested aside, the animal's age may actually explain the significantly higher blood RBA (85-88\%) observed in weaning rats aged 21 days [46,47], compared to that of rats aged 4 weeks and older (0.8-41\%) $[39,40,45,54]$. Also, the 12 -week old rabbits used by Ruby et al. [55] may be more representative of adult digestive conditions, as a 5-week old rabbit absorbs twice as much $\mathrm{Pb}$ as an older rabbit [52]. The declining absorption rates within a relatively short period constitute a challenge in itself, since bioavailability tests must extend over several weeks owing to the half-life of $\mathrm{Pb}$ in blood. During a subchronic testing period of 15-30 days, the weanling rat's $\mathrm{Pb}$ absorption can vary significantly, depending on its age at the start of the testing period.

Specific behavior and defense mechanisms of rats and rabbits also influence absorption. For example, in response to exposure to $\mathrm{Pb}$, rats lower their body temperature, which decreases its RBA. Furthermore, the constant feeding pattern of rats and rabbits and their cellulose-type diet are not favorable to $\mathrm{Pb}$ dissolution in the stomach, as this organ rarely empties completely, resulting in a $\mathrm{pH}$ buffer effect and the constant availability of ligands for $\mathrm{Pb}$ ions [48]. Finally, coprophagic behavior in both species can lead to an inaccurate estimation of $\mathrm{Pb}$ bioavailability, because of $\mathrm{Pb}$ recirculation. Coprophagy is essential to the assimilation of all the nutrients necessary for the growth and development of rodents and rabbits, which, if impeded, can cause deficiencies in some minerals/vitamins that interfere with $\mathrm{Pb}$ absorption. Biliary excretion is also greater in rodents than in humans, and can generate errors in the estimation of $\mathrm{Pb}$ excreted and absorbed [40,46-48]. Despite these differences, rats and rabbits are species commonly used for in vivo experiments, and so are very well characterized. Interpretation of the results, adjustments to them, and extrapolation to humans may therefore be more accurate than for other animal models that are less often used in laboratories. Moreover, even with the marked differences between their digestive systems and those of children, these species remain highly useful for studying many aspects of $\mathrm{Pb}$ exposure, such as estimating the potential health risks of $\mathrm{Pb}$ (e.g., [77]).

Smith Jr. et al. compared Pb bioavailability in weanling micropigs and rats for various test materials, concluding that the micropig model is superior, because of a greater $\mathrm{Pb}$ concentration in their tissues and the ability to detect bioavailability trends in their bones, blood, liver, and kidneys [46]. Juvenile swine appear to be a better surrogate for predicting digestive and absorption processes in infants, because of the similarities between them with respect to: gastric hydrochloric acid $(\mathrm{HCl})$ and protease secretion; small intestine configuration; limited digestive capacity, which impedes solid food digestion; and gut maturity $[34,78]$. At birth, the digestive organs of both species are comparable in size, and the anatomy of the stomach and small intestine is similar. Also, although the immature swine grows faster than the newborn/child, it remains at prepubertal state throughout the experiment [41]. Similar patterns for secretions of $\mathrm{HCl}$, pepsin, and other enzymes are present in the stomach, although gland distribution differs. Stomach capacities for babies at birth, 2 weeks, and 4 weeks approach piglet stomach volumes at 0,10 , and 20 days. Finally, the length of the small intestine and the microscopic gut structure of infants and juvenile swine are similar [78]. Marked differences also exist in the capacity of the digestive tract relative to the body weight of the piglet, which is three times greater than the newborn's. The piglet's stomach volume is $260 \mathrm{~cm}^{3}$, compared to 130 $\mathrm{cm}^{3}$ for infants of the same weight $(5.75 \mathrm{~kg})$. In the piglet, the length of the small intestine increases dramatically within the first ten days of life compared to that of the newborn. This implies that adjustments need to be made, notably in terms of increases in feed levels/dosage. However, the piglet's gastro-intestinal [GI] tract is well characterized, and the relationships between body weight and stomach/small intestine weight/length are known, so that adequate adjustments can be made. To account for the fact that the juvenile swine grows seven times faster than the human baby, intake is expressed relative to gut capacity at similar developmental stages. This rapid growth can be an advantage, since it provides an accelerated model for postnatal human growth and development. Finally, the piglet's size allows serial blood sampling without stressing the animal [78]. However, the cost of conducting piglet experiments can limit the use of this model to investigating multiple substrates. 
USEPA Region VIII scientists conducted in vivo experiments on piglets to estimate the bioavailability of soil $\mathrm{Pb}$ particles, and from there the potential burden for infants/ children $[41,79,80]$. The juvenile swine model experimental procedure for assessing oral bioavailability from soils, detailed in Weis et al. [41] and further developed by Casteel et al. [42], was then applied to a wide variety of soils $[60,63,64,70]$, in some cases with modifications to the original EPA procedure $[46,62]$.

\section{Conditions of dose and application}

The dosage and its frequency are key factors affecting bioavailability estimation [41]. Generally, a fixed quantity of soil/dust is administered based on the estimated average daily soil/dust intake for children, which corresponds to a variable $\mathrm{Pb}$ dosage depending on the $\mathrm{Pb}$ content of the soil. However, for some animal models, such as the rat, it is often necessary to increase dosages in order to increase BLLs to detectable levels that permit reliable differentiation between the PbAc and the test material [45]. Bioavailability results obtained under such conditions may be underestimated, as the rate of elimination of $\mathrm{Pb}$ at these high dosages could be much higher, especially if they largely exceed the saturation concentration for active transport mechanisms in the gut [79].

Childhood soil/dust ingestion rates from hand-tomouth activity refer to small quantities ingested repeatedly during the day, resulting in a cumulative dose of around $100 \mathrm{mg} /$ day [52]. The bioavailability estimation based on in vivo experiments is only valuable if the ingestion of the test material/PbAc and subsequent absorption by the test animal are representative of those of children ingesting $\mathrm{Pb}$ from diet, soil, dust, paint, or water $[48,52]$. Mushak's review stresses that the dosages for in vivo testing should be representative of children's exposure in terms of amount and number of ingestions [52]. For example, the single high dose of $4.2 \mathrm{~g}$ of test material in the Ruby et al. study [55] is not representative of normal children exposure, but more akin to soil geophagia, a form of pica ingestion [52]. Realistic exposures can be achieved by administering lower doses twice daily, as performed in several swine studies in Table $1[42,49,60,61,63-65]$. These studies suggest that realistic dosages administered through multiple daily ingestions are preferable, and represent a better simulation of the exposure of the infant/child.

The choice of a fasting state or a fed state when administering $\mathrm{Pb}$ doses is a major factor in calculating bioavailability, since the stomach's retention time and $\mathrm{pH}$, which are determining factors for $\mathrm{Pb}$ dissolution, depend on that state. In vivo studies presented in Table 1 were performed either in fasting or fed state. The uptake of $\mathrm{PbAc}$ is reduced by about half when $\mathrm{Pb}$ is administered in food, rather than in a fasting state as in rat- based experimental studies [43]. Maddaloni et al. also observed a decrease in RBA of about $24 \%$ from fasting to feeding conditions in human adults after ingesting contaminated soil [38]. The type of food also significantly influences bioavailability, as shown by the wide retention range associated with food type (3.5-56.8\%), as compared to $61.3 \%$ for fasting adults dosed with $\mathrm{PbAc}$ [35]. That study concluded that $\mathrm{Pb}$ ingestion during meals, as well as the presence of calcium, phosphate, and phytate in the meals, notably decreases $\mathrm{Pb}$ bioavailability three hours before and after ingestion. Indeed, calcium, iron, and phosphate were shown to compete with $\mathrm{Pb}$ for absorption through the intestine because of similar uptake mechanisms, although $\mathrm{Pb}$ uptake was not evidenced to occur via active iron transporters or calcium channels [30,34]. Higher estimates of Pb bioavailability were reported for liquids poor in nutritional elements (33-72\%), and the lowest for milk (11-17\%), traditional breakfast (0-8\%), and calcium phytate (1-9\%) [35]. Given the significant impact of food, the fasting state appears to be the conservative choice simulating the worst, but still plausible scenario, since soil, dust, and paint can be ingested by children during playtime between meals. However, $\mathrm{Pb}$ particles ingested via drinking water or formula, or incorporated into food during cooking can be ingested in both the fasting and the feeding state.

\section{In vivo testing of $\mathrm{Pb}$ particles}

Table 1 summarizes results from in vivo experiments completed with $\mathrm{Pb}$-contaminated soils and $\mathrm{Pb}$ paint chips. Significant differences between the animal models, their age, the dosages, the duration, and the calculation method for generating RBA/ABA values must be taken into account when comparing these estimates. The extent of fasting is highly variable in these studies, and only a few studies were conducted in a complete fasting state $[38,55,57,67,68]$.

In conclusion, several experimental factors should be considered, so that the results of in vivo $\mathrm{Pb}$ oral bioavailability estimates using animal models can be extrapolated appropriately to infants and children. In terms of the animal model, juvenile swine carefully controlled for age appear to be the best surrogate for human children. Of all the reported experiments and procedures, the conditions proposed by Casteel et al. [42,49], who used juvenile swine over a subchronic period of 15 days with 0.5-5 g soil (75-675 $\mu \mathrm{g} \mathrm{Pb} / \mathrm{kg}$ bw/day) delivered twice per day, appear the best suited for simulating the conditions of ingestion of soil/dust/paint particles by infants/ children. The bioavailability calculation can be based on BLL estimates, or on a point estimate combining multiple IDMs, such as the widely used AUC for BLL, and the analysis of $\mathrm{Pb}$ accumulated in target tissues, such as 
bone, liver, and kidneys. Such an approach provides information on the distribution of body $\mathrm{Pb}$ and the interaction between accumulated lead in blood, soft tissues, and bones.

\section{In vitro bioaccessibility testing procedures}

Bioaccessibility can be estimated at laboratory scale using chemical extractions of $\mathrm{Pb}$ contaminated test material in solution and under experimental conditions that mimic the mixing and processing of GI fluids. The total recoverable $\mathrm{Pb}$ is generally determined by subjecting a subsample of the test material $[\mathrm{TM}]$ to strong acid digestion, as, for example, in Method 3050 developed by the USEPA for soils and sediments. In vitro bioaccessibility [IVBA] is calculated as follows:

$$
\text { Pb IVBA }=\frac{m g \text { Pb leached in extraction fluid per } g \text { of } T M}{m g \text { total recoverable Pb per } g \text { of } T M} .
$$

Several experimental factors affect the estimates of bioaccessibility yielded by in vitro tests, and their impact varies according to the type and form of the $\mathrm{Pb}$ sources investigated. Choosing an adequate combination of these factors is important for generating bioaccessibility results that can be correlated to bioavailability results. Key factors include the physico-chemical conditions maintained during the in vitro test, especially gastric and intestinal $\mathrm{pH}$, but also the co-presence of food, mixing conditions, the solid to liquid $[\mathrm{S} / \mathrm{L}]$ ratio, and the retention time. Their relative importance is summarized in Table 2. Finally, it should be noted that we discuss all the tests in this section, including those that were not correlated to in vivo data. In fact, although they were not calibrated, the latter tests provide an indication of the trends observed when the parameters of an in vitro test are varied, which makes it possible to rank the importance of each of these parameters.

\section{pH}

$\mathrm{Pb}$ dissolution is very sensitive to $\mathrm{pH}$. The correlation of in vitro to in vivo results for weanling rats, for example, has been shown to be critically dependent on the $\mathrm{pH}$ in gastric simulations [74]. The solubility of mineral species under the conditions that prevail in the stomach and upper intestinal tract determines their bioavailability, the factors affecting solubility being the mineral form, association, inclusion, and size distribution. Overall, chemical species formed under acidic conditions (e.g. $\mathrm{Pb}$ sulfate) will tend to be more stable in simulated acidic conditions and yield lower bioaccessibility values than those formed under alkaline conditions, such as $\mathrm{Pb}$ oxide and $\mathrm{Pb}$ carbonate [69]. Notwithstanding the specific dissolution rates of these forms of $\mathrm{Pb}$, gastric $\mathrm{pH}$ stands out as a dominant factor influencing bioaccessibility results for a similar particle size distribution. For mine waste impacted soil and anglesite soil, Ruby et al. found that the rate of $\mathrm{Pb}$ dissolution was linearly dependent on $\mathrm{HCl}$ content during the first two hours of gastric retention [81]. Yang et al. measured $\mathrm{Pb}$ bioaccessibility values ranging from 50 to $80 \%$ for soil with a gastric $\mathrm{pH}$ of 2 , those figures dropping to 10 to $20 \%$ at pH 3 or 4 [83]. Drexler and Brattin showed that $\mathrm{pH}$ was the most sensitive parameter in the RBALP: a variation in $\mathrm{pH}$ between 1.5 and 3.5 resulted in a variation in bioaccessibility by a factor from 2 to 7 that was only statistically significant above $\mathrm{pH} 2.5$ [84]. Bruce et al. found significantly higher rates of gastric bioaccessibility for mine wastes tested at $\mathrm{pH} 1.3$ (47\%), as compared to $\mathrm{pH}$ 2.5 and 4 (17-18\%) [94]. Oomen et al. concluded that gastric simulation $\mathrm{pH}$ was the major source of variability between the results of a round robin test of five in vitro models [82]. The stability of $\mathrm{pH}$ during the gastric phase also appears to be critical [95]. In fact, Oliver et al. found a higher bioaccessibility (26-46\%) when the $\mathrm{pH}$ of the test was maintained at 1.3 than when the test was performed without any $\mathrm{pH}$ control (20-30\%) [89]. Therefore, $\mathrm{pH}$ should be controlled at the end of the gastric phase, in order to provide the same acidic conditions for the various substrates tested. Results from the RBALP, RIVM, and UBM tests (calibrated) are only considered valid if the $\mathrm{pH}$ at the end of the experiment does not exceed a set reference value $[66,84,86]$.

Juhasz et al. showed that the solubility of PbAc salt decreases greatly under simulated intestinal conditions (pH 4-7.5), reflecting the gradual increase in $\mathrm{pH}$ at the entrance to the intestine: from nearly $100 \%$ at $\mathrm{pH} 1.5$, the IVBA decreases markedly between $\mathrm{pH} 4$ and 6 to about $14.3 \pm 7.2 \%$ at pH 6-7 (Figure 3) [67]. Overall, initial concentrations in the range of 1 to $10 \mathrm{mg} \mathrm{Pb} / \mathrm{L}$ did not influence solubility in the $\mathrm{pH}$ 1.5-7.5 range; slight differences were noted for high dosages of 5 and $10 \mathrm{mg} / \mathrm{L}$ with lower solubility at $\mathrm{pH} 5.5$, and small but significant increases in solubility at $\mathrm{pH}$ 7.5. The steep decrease in PbAc solubility between $\mathrm{pH} 4.0$ and 6.0 corresponds to the gradual increase in $\mathrm{pH}$ in the duodenum and jejunum, where most of the absorption and transport of $\mathrm{Pb}$ cations and complexes is supposed to take place [30,52]. Therefore, an intestinal phase carried out at pH 5.0 may not give the same results as an intestinal phase performed at $\mathrm{pH}$ 7.0. A realistic representation of the intestinal phase would include gradually increasing the $\mathrm{pH}$ and performing a series of sample collections during this increase, but doing so would be a huge challenge and would introduce much variability.

\section{Temperature}

The kinetics of $\mathrm{Pb}$ dissolution is known to be affected by temperature. However, for the conditions typical of in vitro experiments, temperature is not as strong a determinant of 
Table 2 In vitro tests design: main factors affecting bioaccessibility results

\begin{tabular}{|c|c|c|c|c|}
\hline Parameters & $\begin{array}{l}\text { Degree of } \\
\text { Importance }\end{array}$ & General impact on IVBA\% & Notes & $\begin{array}{l}\text { References } \\
\text { (non exhaustive) }\end{array}$ \\
\hline Gastric pH & +++ & - IVBA $\uparrow$ when $\mathrm{pH} \downarrow$ & $\begin{array}{l}\text { - Check the } \mathrm{pH} \text { increase at the end of } \\
\text { the } \mathrm{G} \text { phase. }\end{array}$ & {$[69,81-84]$} \\
\hline \multirow[t]{3}{*}{ Intestinal $\mathrm{pH}$} & \multirow[t]{3}{*}{+++} & - $\downarrow$ IVBA as compared to gastric IVBA & \multirow{2}{*}{$\begin{array}{l}\text { Adjust intestinal IVBA to Pb salt solubility } \\
\text { during the intestinal phase }\end{array}$} & \multirow[t]{3}{*}[65,67,85,86]{} \\
\hline & & - Major $\downarrow$ IVBA from pH 4 to 6 & & \\
\hline & & $\begin{array}{l}\text { - Slight } \uparrow \text { IVBA at pH } 7.5 \text { compared to } \mathrm{pH} \\
\text { 6.0-7.0 }\end{array}$ & $\begin{array}{l}\text { - Increase in solubility of bile/pancreatin-Pb } \\
\text { complexes at pH } 7.5\end{array}$ & \\
\hline Temperature & - & - No impact between $20^{\circ} \mathrm{C}$ and $37^{\circ} \mathrm{C}$ & - May be important when enzymes are added & [84] \\
\hline $\begin{array}{l}\text { Phases } \\
\text { simulated }\end{array}$ & +++ & - Gastric IVBA > Intestinal IVBA & $\begin{array}{l}\text { - Adjust intestinal IVBA to Pb salt solubility } \\
\text { during the intestinal phase }\end{array}$ & {$[67]$} \\
\hline Extraction & + & $\begin{array}{l}\text { - IVBA } \downarrow \text { in the range: centrifugation > } \\
\text { microfiltration > UF }\end{array}$ & $\begin{array}{l}\text { - No difference between } 0.2 \text { and } 0.45 \mu \mathrm{m} \\
\text { filtration }\end{array}$ & {$[84,87]$} \\
\hline \multirow{3}{*}{$\begin{array}{l}\text { Fluid } \\
\text { composition }\end{array}$} & \multirow[t]{3}{*}{+} & - Contradictory results ( $\uparrow$ or $\downarrow$ IVBA) & \multirow{2}{*}{$\begin{array}{l}\text { - Physiologically based fluids may be important } \\
\text { when food is added }\end{array}$} & \multirow[t]{3}{*}[55,67,85,88-90]{} \\
\hline & & \multirow{2}{*}{$\begin{array}{l}\text { - Physiologically based fluids do not } \\
\text { seem important for the } G \text { phase }\end{array}$} & & \\
\hline & & & $\begin{array}{l}\text { - Bile/pancreatin would create soluble complexes } \\
\text { with Pb }\end{array}$ & \\
\hline \multirow{2}{*}{$\begin{array}{l}\text { Retention } \\
\text { time }\end{array}$} & \multirow[t]{2}{*}{++} & - IVBA $\uparrow$ when gastric phase time $\uparrow$ & \multirow{2}{*}{$\begin{array}{l}\text { - Lower impact on more soluble } \mathrm{Pb} \text { forms: } \\
\text { IVBA plateau reached after 20-30 min }\end{array}$} & \multirow[t]{2}{*}[55,74,88,91]{} \\
\hline & & $\begin{array}{l}\text { - No information on intestinal extraction } \\
\text { time effect }\end{array}$ & & \\
\hline Mixing & ++ & - Aggressive mixing (Ar gas) $\uparrow$ IVBA & $\begin{array}{l}\text { - End-over-end agitation adapted to maximize } \\
\text { solid/fluid contact, but not too aggressive }\end{array}$ & {$[69,74,84]$} \\
\hline \multirow{2}{*}{$\begin{array}{l}\text { S/L ratio } \\
(\mathrm{g} / \mathrm{mL})\end{array}$} & \multirow[t]{2}{*}{+++} & - IVBA $\downarrow$ with high $S / L>1 / 100$ & - High $S / L \uparrow$ the effect of $\mathrm{TM}$ on $\mathrm{pH} \uparrow$ & \multirow[t]{2}{*}[83,84,92]{} \\
\hline & & $\begin{array}{l}\text { - No effect between low ratio } 1 / 100 \text { and } \\
1 / 5000\end{array}$ & - Low ratios $(<1 / 125)$ give poorer reproducibility & \\
\hline \multirow{2}{*}{$\begin{array}{l}\text { Food } \\
\text { addition }\end{array}$} & \multirow[t]{2}{*}{+++} & \multirow[t]{2}{*}{ - IVBA $\downarrow$ with food, except powdered milk } & - Effect variable depending on food type & \multirow[t]{2}{*}[62,87,88,93]{} \\
\hline & & & - Fed tests linked to lower recovery rates & \\
\hline
\end{tabular}

+++ high importance, ++ moderate importance, + light importance, - no importance, based on the studies published to date.

$\mathrm{Pb}$ dissolution as it is of the optimal activity of enzymes in the digestive juices. Drexler and Brattin found no significant difference between the RBALP results obtained at ambient temperature and those at human body temperature for seventeen test materials [84]. Most of the procedures apply a $37^{\circ} \mathrm{C}$ temperature by default, since temperature is a fixed parameter in the digestive process and closely mimics biological conditions.

\section{Separation of the liquid from the solid}

The separation method is an essential step in determining the bioaccessible $\mathrm{Pb}$ fraction [87], and the definition of the separation limit between particulate and dissolved $\mathrm{Pb}$ varies significantly in the literature and between models. Extraction can be achieved by centrifugation (e.g. $[55,82,96])$, centrifugation followed by filtration of the supernatant (e.g. $[83,94])$, or direct filtration (e.g. [84,89]). Others have used epithelial Caco-2 cells, in order to better represent the intestinal wall morphology [97]. Also, an aliquot of the digestion product can be analyzed directly, based on the hypothesis that the analytical instrument will only detect dissolved $\mathrm{Pb}[26,98]$.

In the absence of an extraction step, the digestion product should be analyzed immediately. Centrifugation can be applied at various combinations of rotational speed and time, which can influence separation and impact estimates of bioaccessible $\mathrm{Pb}$. In filtration, the filter cut-off varies. Several studies used $0.45 \mu \mathrm{m}$ filters $[84,88,89]$, others used $0.2 \mu \mathrm{m}$ filters $[67,94]$, while the TIM model recommends ultra-filtration [UF] [82,87]. However, filtration at the end of the intestinal phase may bias results, since some filter materials are known to absorb dissolved $\mathrm{Pb}$ at neutral $\mathrm{pH}$, the absorbed quantity varying with $\mathrm{Pb}$ concentration [99].

The impact of the various extraction methods identified above can be classified by the magnitude of bioaccessibility, as follows: no extraction $>$ centrifugation $>$ microfiltration > UF > Caco-2 cells. Van De Wiele et al. applied various extraction methods to the fed-RIVM, and bioaccessibility decreased from $31.5 \%$ (centrifugation) to $22 \%$ (microfiltration) to $3.5 \%$ (UF) [87]. Bioaccessibility results with UF were the closest to in vivo data on the same single soil tested [38,87]; however, the authors stress that these results are less reliable. Finally, Drexler and Brattin found no significant difference between bioaccessibility estimated with a filtration at $0.45 \mu \mathrm{m}$ and one at $0.2 \mu \mathrm{m}$, suggesting that non bioaccessible $\mathrm{Pb}$ would be mainly particles $>0.45$ $\mu \mathrm{m}$ for the test materials in question [84]. 


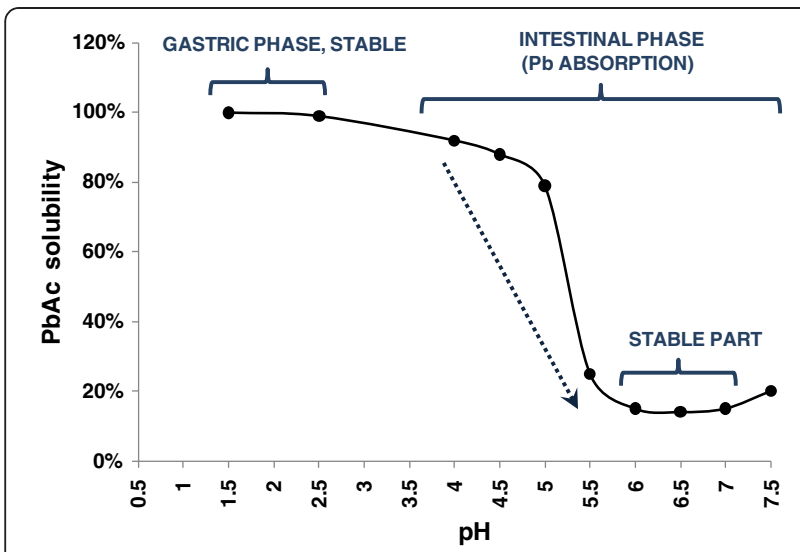

Figure 3 Changes in $\mathrm{Pb}$ acetate ( $\mathrm{PbAc}, 1-10 \mathrm{mg} \mathrm{Pb} / \mathrm{L}$ ) solubility with $\mathrm{pH}$, during the gastric and intestinal phases. Adapted from [67].

\section{Fluid composition}

The primary function of digestive enzymes is the decomposition of proteins (pepsin and trypsin) and carbohydrates (pancreatic and small intestine enzymes), while bile emulsifies lipids.

Oliver et al. showed that adding pepsin to the gastric fluid decreased the amount of dissolved $\mathrm{Pb}$ by about $28 \%$. However, gastric $\mathrm{pH}$ did not remain constant, in fact, $\mathrm{pH}$ was increasing from 1.3 to 3 after the addition of the dust substrate, and this may be the factor responsible for the decreased bioaccessibility [89]. Conversely, Medlin compared bioaccessibility results using a physiologicallybased gastric fluid and diluted $\mathrm{HCl}$, and found little difference for cerussite, anglesite, and SRM 2710 at $\mathrm{pH} 1.5$ [88]. However, at $\mathrm{pH} 2.8$, the use of pepsin-based fluid increased bioaccessibility significantly (by up to $42 \%$ ). Finally, Drexler and Brattin showed that the addition of enzymes was unnecessary for achieving a good in vivoin vitro relationship using the validated RBALP procedure, which only simulates a gastric phase [84]. Consequently, for tests simulating this phase, the addition of enzymes appears unnecessary.

The simulation of physiological secretions may, however, be important for intestinal extraction. Ruby et al. found an increase in bioaccessibility of about $20 \%$ with the addition of organic acids and/or enzymes [55]. This was explained by the chelating characteristics of organic acids and by the binding of $\mathrm{Pb}$ to organic acids and enzymes, which kept the $\mathrm{Pb}$ dissolved in the intestinal fluid and prevented precipitation. Moreover, Juhasz et al. explained the increase in $\mathrm{Pb}$ solubility at $\mathrm{pH} 7.5$ (compared to $\mathrm{pH}$ 6.0-7.0) by the formation of organo (pancreatin/bile)-Pb complexes [67]. Oomen et al. have suggested that the formation of $\mathrm{Pb}$-bile complexes could increase $\mathrm{Pb}^{2+}$ concentrations [85]. In addition, the bioaccessibility results of Oomen et al. were about 10 to $40 \%$ higher for chicken bile than for ox or pig bile, which means that bile will affect bioaccessibility differently, depending on its animal origin [90]. Finally, in the case of an in vitro procedure simulating a fed state, the introduction of food may require the addition of enzymes and bile from both the gastric and intestinal phases, since they play a role in food degradation prior to absorption and in $\mathrm{Pb}$ complex formation [87].

\section{Retention time}

Retention times vary considerably between test methodologies and can impact the estimates of Pb bioaccessibility. Intuitively, for particles with limited solubility, longer stomach retention time should enhance bioaccessibility, since the extent of $\mathrm{Pb}$ dissolution increases with more contact time at a given rate. Ruby et al. evaluated $\mathrm{Pb}$ bioaccessibility in the stomach and intestine, and observed an average increase of $4.8 \%$ between $30 \mathrm{~min}$ and $1 \mathrm{~h}$ during the gastric phase, while an unsystematic decrease was noted during the intestinal phase [74]. Gasser et al. studied $\mathrm{Pb}$ dissolution in a stomach environment using a stirred flow reactor, and observed an initial rapid increase in $\mathrm{Pb}$ dissolution rate, which tended to decrease over time $(0-60 \mathrm{~min})$ and $\mathrm{pH}(1-3)$ [91]. Both the time and $\mathrm{pH}$ increment of this dissolution rate was substrate dependent. Moreover, Ruby et al. stated that, if the dissolution of the $\mathrm{Pb}$-bearing mineral is controlled by a surface reaction rate, then the transit time will control that dissolution, suggesting that the impact of retention time in an in vitro test will depend on the form of the substrate studied [69]. For low solubility minerals, the dissolution kinetics would be controlled by surface reactions, and so the major parameter governing $\mathrm{Pb}$ release during digestion for these minerals would be stomach retention time. This is illustrated by Medlin's results: less soluble $\mathrm{Pb}$ bearing minerals (anglesite, pyromorphite, galena) exhibited the highest dissolution rate, which continued to rise after the $1 \mathrm{~h}$ stomach simulation, whereas more soluble $\mathrm{Pb}$ ones (e.g. cerussite) generally reached a plateau after the first $20 \mathrm{~min}$ of the gastric simulation [88]. In another study, however, Drexler and Brattin applied 1,2, and $4 \mathrm{~h}$ retention time to 11 substrates from comparable sources (mining sites) and found no significant differences [84].

\section{Mixing}

Determination of the mixing type and intensity depends on the test material studied. Ruby et al. stated that mixing controls the dissolution of $\mathrm{Pb}$ bearing materials through transport mechanisms [69]. For more soluble minerals, the kinetics of dissolution are controlled by transport mechanisms in which dissolved ions are quickly detached from the particle surface, accumulate, and form a saturation solution at the boundary layer. In addition, mixing conditions should be set to keep the $\mathrm{Pb}$ 
particles in suspension. Ruby et al. mixed by means of argon [Ar] injection, which efficiently kept the particles in suspension, but this type of aggressive mixing may overestimate bioaccessibility [74]. According to Drexler and Brattin, end-over-end mixing is the most appropriate for such experiments, because it maximizes the contact between sample and fluid (substrate surface area), and consequently $\mathrm{Pb}$ dissolution rate, and minimizes contamination caused by interacting devices (paddle, etc.) [84]. Moreover, it prevents the test material from sticking to the bottom of the tube/beaker, as observed for procedures using shaking water-bath (the authors' observations in the laboratory).

\section{Solid to liquid ratio [S/L]}

The $\mathrm{S} / \mathrm{L}$ ratio is another major factor impacting $\mathrm{Pb}$ dissolution and the resulting bioaccessibility estimation. According to Dean and Ma, the most common $\mathrm{S} / \mathrm{L}$ ratios used for in vitro extractions vary between $1 / 2$ and $1 / 250 \mathrm{~g}$. $\mathrm{mL}^{-1}$ [100]. Lower ratios, such as $1 / 1800$ [101], 1/2160 [102], 1/5000 [92], and 1/16,667 [26], are also reported. The gastric ratio should be limited to reduce the effect of metal dissolution (observed for $1 / 5$ and $1 / 25$ ratios) and to prevent $\mathrm{Pb}$ chloride crystal precipitation upon cooling (for media containing over $50,000 \mathrm{mg} \mathrm{Pb} / \mathrm{kg}$ ) [84]. However, gastric ratios as high as $1 / 2.5$ [82], $1 / 10$ (e.g. [55,89]) and $1 / 30$ to $1 / 40$ have been applied (e.g. $[103,104])$. Such ratios may also increase the positive impact of the test material on the $\mathrm{pH}$, if the latter is not controlled, and consequently underestimate bioaccessibility ([86]). For the same BMW soil and similar PBET conditions at a $1 / 100$ ratio, Ruby et al. found higher bioaccessibility (9.5-35\%) than at a $1 / 10$ ratio $(\leq 6 \%)$ [74]. The $1 / 10$ ratio used in Oliver et al. may have influenced the low bioaccessibility range found for dusts (20-30\%), compared to other studies on dust for which $\mathrm{Pb}$ bioaccessibility generally exceeded $50 \%$ in the gastric phase [89]. Yang et al. demonstrated that $\mathrm{Pb}$ bioaccessibility in soil increased by about $10 \%$ between gastric ratios of $1 / 40$ and $1 / 100$ [83]. Hamel et al. had concluded that $\mathrm{Pb}$ bioaccessibility was only slightly affected with ratios between $1 / 100$ and 1/5000 [92]. Medlin found that the $\mathrm{Pb}$ bioaccessibility of SRM 2710 soil increases by about $11 \%$ between the ratios $1 / 100$ and $1 / 500$ [88]. Drexler and Brattin standardized the procedure and recommended applying a ratio of $1 \mathrm{~g}$ of substrate per $100 \mathrm{~mL}$ fluid for media containing $\mathrm{Pb}$ in amounts less than $5 \%$ by weight $(0.5 / 100$ for substrates $>5$ wt $\% \mathrm{~Pb})$ [84]. Ratios below $1 / 125$ are not recommended because of poorer reproducibility (substrate heterogeneity, weighing errors), as well as issues with the detection of low $\mathrm{Pb}$ concentrations during subsequent analysis. The effect of the $\mathrm{S} / \mathrm{L}$ ratio during the intestinal phase has not been studied systematically, but could influence the precipitation reactions and also the stability of the solution, which has been shown to be difficult to maintain.

\section{Food/substrate}

The presence of food/substrate during digestion and its type will influence bioaccessibility, and a systematic decrease in bioaccessibility following the addition of food has been reported in most in vitro experiments, especially for gastric phase results. Indeed, dissolved $\mathrm{Pb}$ is adsorbed on non-digested elements, and forms complexes with some elements. Scheckel and Ryan found a $\mathrm{Pb}$ bioaccessibility close to zero for highly soluble hydrocerussite-based paint after the addition of a cola soft drink to the gastric fluid [93]. These results were explained by the reaction of soluble $\mathrm{Pb}$ with phosphates in the drink to form pyromorphite solid. Results obtained by Schroder et al. showed that the median bioaccessibility without dough added was $36.3 \%$ and $0.62 \%$ for the gastric and the intestinal phase respectively, while the test performed with dough resulted in bioaccessibility medians of $27 \%$ and $0.58 \%$ [70]. The swallow model performed by Brandon et al. in fasting conditions estimated the $\mathrm{Pb}$ bioaccessibility of 'real-life' paint at about $10 \%$, while it was about $4.5 \%$ for the test performed with $4.5 \mathrm{~g}$ of infant food [101]. This decrease may be partly attributed to the difference in the stomach $\mathrm{pH}$ used to simulate a fasting state (1.6) or a fed state (2.5), but the presence of food may also have an influence. Additionally, the RIVM and TIM models run with and without solid food for the same soil resulted in higher bioaccessibility values for the fasting state $\mathrm{m}$ (32-47\%) than for the fed state (RIVM: 24-39\%; TIM: 7\%) [87]. Retention times and $\mathrm{pH}$ were quite close between the tests performed with and without food, suggesting that food would be partly responsible for this decrease. Recovery efficiencies influence these estimates, and the fed tests were linked to lower recoveries (70-93\%) than were observed in fasting tests ( $\geq 83 \%$ ) [87].

Remarkably, some studies performed with whole milk powder show the opposite trend, with an increase in bioaccessibility in a fed state. Marschner et al.'s twophase enzymolyzis showed higher bioaccessibility for the fed state (11-56\%) than for the fasting state (2-21\%) [62]. With controlled retention time, $\mathrm{pH}$, and fluid formulas, Van De Wiele et al. observed a higher bioaccessibility with the addition of whole milk powder to the fluid for the PBET and DIN tests (fed: 22-29\%; fasting: 13-14\%) [87]. Medlin investigated different types of food (banana, milk, oatmeal, and rice) and substrates ( $\mathrm{Pb}$ phosphates, slag, galena, and $\mathrm{Pb}$ oxide) [88]. Trends varied depending on the food, the $\mathrm{Pb}$ form, and the amount tested, showing the huge challenges involved in the design of a representative fed state [84]. 
In vitro testing bioaccessibility procedures and validation Various methods have been published to investigate the bioaccessibility of $\mathrm{Pb}$ particles in environmental media, using simple to more complex methodologies aimed at reproducing to a varying extent the conditions in the digestive tract to which the particles are exposed. These methods can be classified in two categories:

1. Non physiologically based tests simulating the conditions of acidic $\mathrm{pH}$ and retention time in the stomach, without enzymes or other physiological fluids representative of real digestive conditions (or only additions that were shown to impact IVBA), namely: $\mathrm{HCl}$ extractions, the Relative Bioaccessibility Leaching Procedure [RBALP] or Simple

Bioaccessibility Extraction Test [SBET], the Solubility Bioavailability Research Consortium procedure [SBRC], and variants of these tests.

2. Physiologically based extraction tests which attempt to simulate the physiological fluids and conditions of the digestive tract, namely: the Physiologically Based Extraction Test [PBET], the In Vitro Gastrointestinal method [IVG], the RIVM model, the Unified Barge Method [UBM], the DIN model, the TIM model, the SHIME model, and variants of these tests, either dynamic or static.

Table 3 summarizes the results obtained for the same test materials using various in vitro procedures. Depending on the procedure applied, the estimated IVBA varies widely, especially the intestinal IVBA. Results obtained with different in vitro test designs should be compared with caution, in light of the differences in testing conditions discussed previously. A more important aspect to consider is whether or not these tests provide estimates of bioaccessibility that are useful for refining bioavailability and $\mathrm{Pb}$ exposure assessments. In fact, the main objective of a bioaccessibility test is to offer a rapid and low cost alternative to bioavailability testing. Therefore, the optimal bioaccessibility test should produce data that can be adequately correlated to in vivo data. In vivo to in vitro correlation [IVIVC] can be used to calibrate in vitro testing conditions, which is highly desirable as it would ensure that an in vitro method is an acceptable alternative to animal investigations. These correlations are usually presented as linear regression models, and their strength will depend on the number of substrates tested and the range of IVBA/RBA available. According to Drexler and Brattin, a strong correlation is determined by an $\mathrm{R}^{2}>0.6$ and a significant relationship with a slope as close as possible to 1 [84]. However, it is suggested that the correlation coefficient may be more important than the slope, since a slope $\neq 1$ does not impede linking IVBA to RBA [105].
Another important aspect to consider in the selection of the in vitro testing procedure is the validation of the in vitro test. In vitro procedures should ideally be subjected to round robin testing to verify the ability of the results to be accurately reproduced or replicated. Interlaboratory testing is needed to standardize the procedure, so that it can be applied in any laboratory on multiple test materials [65,84]. For example, the UBM procedure is considered valid when the relative standard deviation (RSD) of within-laboratory results and between-laboratory results was $\leq 10 \%$ and $\leq 20 \%$ respectively [95]. Then, multiple low cost experiments can be completed and extrapolated using existing data on animals and/or humans, and can be expected to be semi-quantitatively accurate. In vitro procedures that have not been calibrated or validated can nevertheless be useful, but should be considered as approximations and interpreted with caution.

\section{In vitro test results compared to in vivo data}

Table 4 lists in vitro tests that have been correlated to in vivo data, including variants of the PBET and IVG procedures: RIVM, UBM, RBALP, and SBRC.

\section{PBET and IVG procedures}

Numerous authors have used in vitro systems to estimate the bioavailability of inorganic elements. The PBET introduced by Ruby et al. $[55,74]$ based on their previous work, was the first test for $\mathrm{Pb}$ particles that used simulated biological fluids in both the gastric and intestinal phases, and that correlated the results to in vivo data. As shown in Table 4, a synthetic gastric fluid composed of $\mathrm{HCl}$, pepsin, and organic acids is added to the soil sample in a $1 / 100$ g. $\mathrm{mL}^{-1}$ ratio. Initial incubation is performed at $37^{\circ} \mathrm{C}$ with varying initial $\mathrm{pH}(1.3,2.5,3.0$, and 4.0 ), reflecting different digestion conditions under mixing with argon. After an hour, the $\mathrm{pH}$ is progressively adjusted to 7.0 using sodium bicarbonate $\left[\mathrm{NaHCO}_{3}\right]$, simulated intestinal fluids (pancreatin and bile) are added, and mixing is continued for another four hours. The mixture is then centrifuged and settled, and the supernatant analyzed. A similar PBET test was developed by Medlin, using a comparable gastric S/L ratio and the similar synthetic gastric fluid formula [88]. The impact on the results of modifying the $\mathrm{pH}$, time, particle size, and food addition, as well as the addition of a twohour intestinal phase, was investigated. The final test applied only a gastric phase at $\mathrm{pH} 1.5$ for $1 \mathrm{~h}$, with continuous $\mathrm{pH}$ measurement, a mixing step combining $\mathrm{Ar}$ gas on the surface of the reaction vessel with the stirring rod moving at $60 \mathrm{rpm}$, and an extraction via $0.45 \mu \mathrm{m}$ filtration. Brown et al. and Hettiarachchi et al. applied a similar version of PBET, as recommended by Ruby et al. [74], although the intestinal phase was either not simulated or faster $(1 \mathrm{~h})$ [58,59] (Table 4). 
Table 3 Comparison of bioaccessibility results obtained with the same test materials

\begin{tabular}{|c|c|c|c|c|}
\hline MATERIAL & TEST TYPE & GASTRIC IVBA \% & INTESTINAL IVBA \% & REFERENCES \\
\hline Montana & PBET & 67.3 & & [88] \\
\hline SRM 2710 soil & PBET & $29 \pm 5$ to $46 \pm 29$ & & [92] \\
\hline \multirow[t]{6}{*}{ RBA $76 \%^{+}$} & PBET & & $54-62 \pm 1^{*}$ & [102] \\
\hline & PBET & $76.1 \pm 11$ & $10.7 \pm 2.3$ & {$[57]$} \\
\hline & PBET & & $30-35$ & {$[90]$} \\
\hline & RIVM & $79 \pm 4$ & $25 \pm 1$ & [96] \\
\hline & RBALP & $75 \pm 5$ & & {$[84]$} \\
\hline & UBM & 75 & 27 & {$[65]$} \\
\hline Montana & DIN & & $46 \pm 2$ & {$[82,90]$} \\
\hline \multirow[t]{8}{*}{ SRM 2711 soil } & SHIME & & $3 \pm 0.3$ & \\
\hline & TIM & & $17 \pm 3$ & \\
\hline & RIVM & & $11 \pm 2$ & \\
\hline & SBET & $90 \pm 2$ & & \\
\hline & PBET & & 10-20 (60 for chicken bile) & \\
\hline & PBET & $85 \pm 5$ & $13 \pm 1$ & {$[96]$} \\
\hline & RBALP & $84 \pm 6$ & & {$[84]$} \\
\hline & UBM & 80 & 33 & {$[65]$} \\
\hline Bunker Hill soil & PBET & 75 & & {$[88]$} \\
\hline \multirow[t]{7}{*}{ RBA adults $62 \pm 25 \%^{\neq}$} & PBET & & $70 \pm 11^{*}$ & [102] \\
\hline & RIVM & $87.6 \pm 8.4$ & $45.4 \pm 4.0$ & {$[86]$} \\
\hline & PBET & & $13 \pm 0.8$ & {$[87]$} \\
\hline & DIN & & $13.6 \pm 0.6$ & \\
\hline & SHIME & & $2.0 \pm 0.1$ & \\
\hline & RIVM & & $31.8 \pm 2.5-47.4 \pm 3.2$ & \\
\hline & TIM & & $32.5 \pm 4.5$ & \\
\hline \multirow[t]{5}{*}{ Flanders soil } & DIN & & $31 \pm 3$ & {$[82]$} \\
\hline & SHIME & & $4 \pm 1$ & \\
\hline & TIM & & $13 \pm 3$ & \\
\hline & RIVM & & $66 \pm 9$ & \\
\hline & SBET & $91 \pm 4$ & & \\
\hline \multirow[t]{7}{*}{ Oker 11 soil $R B A 55 \%^{\S}$} & DIN & & $16 \pm 2$ & {$[82]$} \\
\hline & SHIME & & $1 \pm 0.1$ & \\
\hline & TIM & & $4 \pm 1$ & \\
\hline & RIVM & & $29 \pm 2$ & \\
\hline & SBET & $56 \pm 4$ & & \\
\hline & IVG & & 20 & {$[62]$} \\
\hline & SBRC & $66.8 \pm 2.3$ & $62.9 \pm 11$ & {$[67]$} \\
\hline
\end{tabular}

IVBA-in vitro bioaccessibility; ${ }^{*}$ bioaccessible $\mathrm{Pb}(\mathrm{mg})$ included Pb leached in G\&I phases; ${ }^{+} R B A$ on juvenile swine [65]; ${ }^{\ddagger} R B A$ on human adults $[38,86] ;{ }^{s} R B A$ on juvenile swine [62].

Tests simulating a fasting state.

Results from the gastric phase using the Ruby et al. [74] procedure were calibrated for $\mathrm{Pb}$ in mine wastes with previous in vivo studies on Sprague Dawley rats. Only in vitro results of the gastric phase at $\mathrm{pH} 1.3$ and 2.5 were linearly correlated to in vivo results $\left(R^{2}=0.93\right)$, with a slope closer to 1 at $\mathrm{pH} 2.5$ [45,71-74]. The procedure by Medlin also showed that gastric bioaccessibility predicted in vivo juvenile swine data better than intestinal bioaccessibility (Table 4) [88]. Bioaccessibility estimates from the intestinal phase (tested for SRM 2710 
and $\mathrm{Pb}$ oxide) underestimated the bioavailability data from in vivo calibration studies. Brown et al. observed a significant relationship between gastric RBA reduction and IVBA reduction following different $\mathrm{Pb}$ remediation methods performed on the tested soil [58]. Finally, Hettiarachchi et al. observed a stronger correlation of the RBA point estimates in rats with gastric IVBA, than with intestinal IVBA (Table 4) [59]. This lack of strong and significant correlations demonstrates the extent of the challenges in relating intestinal phase results from PBET to in vivo data, possibly due to precipitation reactions and the complexity of the mechanisms involved in intestine wall absorption.

Although the demonstration of a strong correlation with an animal model is highly valuable, the significance of the calibration is maximized if it is obtained using an adapted animal model that can be used to estimate exposure and risk assessment in human populations. The IVIVC observed for the PBET using rats [59,74], although significant, may not be as valuable for studying childhood exposure, however, because of the in vivo test design (animal model and/or dose administered), as underlined by Mushak [52]. In contrast, the PBET later developed by Medlin was correlated to in vivo data in juvenile swine [88], which are considered to be a better model for simulating digestion and absorption processes in children. In addition, this test was performed on a significant number of soils $(n=15)$ using an extensive QA/QC protocol. Therefore, it appears to be more reliable than the Ruby et al. initial PBET [74]. Nonetheless, this test has not been subjected to the interlaboratory validation and statistical analysis that would demonstrate good laboratory reproducibility of the results.

The IVG model, initially developed for PAH and PCB [106], was subsequently applied to $\mathrm{Pb}$. It reproduces the PBET gastric and intestinal phases using physiological fluids, but the formulation of the fluids, retention time, and $\mathrm{pH}$ are different (Table 4). Schroder et al. and Marschner et al. compared the IVG results to in vivo results on swine using the same soils $[62,70]$. The absence of IVIVC in the Marschner et al. (2006) study was attributed to the technical difficulties during the intestinal phase simulation. However, Schroder et al. did find significant relationships between in vivo and in vitro results performed with and without dough: blood-based bioavailability was correlated to gastric in vitro results $(\mathrm{R}=0.93 ; \mathrm{p}<0.001)$ and to intestinal in vitro results $(\mathrm{R}=0.80 ; \mathrm{p}<0.001)$ with dough. In vitro tests performed without dough showed significant correlation to in vivo blood-based bioavailability in the gastric phase, but not in the intestinal phase (Table 4) [70]. However, the in vivo data used for this correlation were later corrected by Casteel et al. and the USEPA $[42,43]$, and so the relationship would need to be re-evaluated with the corrected data prior to any use for other test materials.
Finally, this test cannot be considered as a fully validated standardized in vitro procedure, because of the limited use of a QA/QC protocol and incomplete statistical analysis [84]. Nonetheless, it can be noted that, here again, the highest correlation was observed with in vitro gastric results.

\section{RBALP and SBRC procedures}

Considering the apparently good correlation of bioavailability and gastric bioaccessibility and the limited benefit of including an intestinal phase [88], a protocol reproducing only the gastric phase was developed in Dr. John Drexler's laboratory. The RBALP was proposed after some investigation into the impact of temperature, contact time, $\mathrm{pH}$, and $\mathrm{S} / \mathrm{L}$ ratio to maximize correlation to in vivo data $[84,88]$. The RBALP includes an extraction with a synthetic fluid composed of glycine and $\mathrm{HCl}$ at $37^{\circ} \mathrm{C}\left(1 \mathrm{~h}, \mathrm{pH}\right.$ of $1.5,1 / 100$ g.mL $\left.\mathrm{mL}^{-1}\right)$. End-over-end mixing is performed $(28 \pm 2 \mathrm{rpm})$, and separation is achieved via filtration at $0.45 \mu \mathrm{m}$. The test also includes criteria allowing for rigorous, reliable, and reproducible results that are only considered valid if: (1) the $\mathrm{pH}$ at the end of the extraction is within 0.5 units of the initial $\mathrm{pH}$, which ensures that glycine buffering capacity is not exceeded; (2) the maximum holding time before analysis is one week; and (3) a rigorous QA/QC protocol is applied, including analysis of a bottle blank, a blank spike, a matrix spike, a duplicate sample, and a control soil at a $5-10 \%$ frequency. The test was applied to two SRM materials and nineteen test materials through round robin testing by four laboratories, and the results were compared via a statistical analysis. Intra-laboratory results showed good precision and agreement, with a CV of 2-6\%, and the laboratory results respecting SRM standards were highly reproducible (CV of $7 \%)$. These observations confirm good reproducibility, precision, and standardization of the method.

As shown in Table 4, the RBALP was highly correlated to in vivo juvenile swine results using the nineteen test materials, including one NIST paint, galena, and soils impacted by mining and smelting activities [42,84]. Moreover, it is easier to perform than the PBET, because of the formulation of the synthetic fluids and the rapidity of the test. The British Geological Survey adapted the RBALP and renamed it the Simple Bioacessibility Extraction Test (SBET). The SBET protocol has been applied with some modifications [83,107]. Others applied the original RBALP [64,108,109]. The test applied to eight soils of small shooting ranges also revealed results comparable to an in vivo swine study (Table 4) [64]. Considering the number of substrates tested with the RBALP, which was calibrated with in vivo data on a recognized representative animal model and the results confirmed through a validation method, a rigorous QA/QC 
Table 4 In vitro procedures applied to $\mathrm{Pb}$ particles and compared with in vivo data for subsequent calibration (2 pages)

\begin{tabular}{|c|c|c|c|c|c|}
\hline References & Substrate & Oral phase & Gastric phase & Intestinal phase & Comparison with in vivo data \\
\hline \multirow{2}{*}{$\begin{array}{l}\text { Ruby et al. } 1993 \\
\text { PBET-GI [55] }\end{array}$} & \multirow{2}{*}{\multicolumn{2}{|c|}{ Mine wastes }} & $1 / 10 \mathrm{~g} \cdot \mathrm{mL}^{-1}$ & $2 \mathrm{~h} @ \mathrm{pH} 7.0$ & \multirow{2}{*}{$\begin{array}{l}\text { - In vivo results on rabbits (1 sample): } 10.7 \% \\
\text { (blood based RBA at } \mathrm{t}=1 \mathrm{~h} \text { ), and } 9^{ \pm 4} \% \\
\text { (gastric solubility, } \mathrm{t}=1.5 \mathrm{~h} \text { ) }\end{array}$} \\
\hline & & & $\begin{array}{l}2 \mathrm{~h} @ \mathrm{pH} 1.3 \text { Pepsin; } \\
\text { organic acids; } \mathrm{HCl}\end{array}$ & $\mathrm{NaHCO}_{3}$; pancreatin; bile & \\
\hline \multirow{3}{*}{$\begin{array}{l}\text { Ruby et al. } 1996 \\
\text { PBET-GI [74] }\end{array}$} & \multirow{3}{*}{\multicolumn{2}{|c|}{$\begin{array}{l}\text { Mine wastes Residential } \\
\text { soils Tailings }\end{array}$}} & $1 / 100 \mathrm{~g} \cdot \mathrm{mL}^{-1}$ & $4 \mathrm{~h} @ \mathrm{pH} 7.0$ & \multirow{2}{*}{$\begin{array}{l}\text { - In vivo relative Pb bioavailability in rats } \\
\text { (based on } B L L S, Y \text { axis) correlation to IVBA } \\
\text { results from the } G \text { phase ( } X \text { axis): } \\
R^{2}=0.93, n=7 \text {, intercept } 3.2 \text {, slope } 1.4\end{array}$} \\
\hline & & & $\begin{array}{l}1 \mathrm{~h} @ \mathrm{pH} 2.5 \text { Pepsin; } \\
\text { organic acids; } \mathrm{HCl}\end{array}$ & $\mathrm{NaHCO}_{3}$; pancreatin; bile & \\
\hline & & & & & - Correlation with I phase: $\mathrm{R}^{2}=0.76$ \\
\hline \multirow{3}{*}{$\begin{array}{l}\text { Medlin } 1997 \\
\text { PBET-G [88] }\end{array}$} & \multirow{3}{*}{$\begin{array}{l}15 \text { soils or soil-like materials } \\
\text { (EPA Region VIII) }\end{array}$} & & $1 / 111 \mathrm{~g} \cdot \mathrm{mL}^{-1}$ & & $\begin{array}{l}\text { - In vivo point estimates in piglets (Y-axis) correlated to } \\
\text { in vitro results (X-axis): }\end{array}$ \\
\hline & & & \multirow{2}{*}{$\begin{array}{l}1 \mathrm{~h} @ \mathrm{pH} 1.5 \text { Pepsin; } \\
\text { organic acids; acetic } \\
\text { acids; } \mathrm{HCl}\end{array}$} & & $\begin{array}{l}\text { In vitro results ( } X \text {-axis): } \\
R^{2}=0.63, n=15 \text {, intercept }-8.21 \text {, slope } 0.90, p<0.001^{*}\end{array}$ \\
\hline & & & & & • Extensive QA/QC protocol \\
\hline \multirow{2}{*}{$\begin{array}{l}\text { Brown et al. } 2003 \\
\text { PBET-G [58] }\end{array}$} & \multirow{2}{*}{$\begin{array}{l}\text { Urban soil treated with } \\
\text { various biosolids }(n=9)\end{array}$} & & $1 / 100 \mathrm{~g} \cdot \mathrm{mL}^{-1}$ & & \multirow{2}{*}{$\begin{array}{l}\text { - In vivo bone bioavailability reduction \% in rats } \\
\text { correlated to in vitro bioaccessibility reduction } \\
\text { with the treatment of soils }(R=0.9)\end{array}$} \\
\hline & & & $\begin{array}{l}1 \text { h @ pH } 2.3 \text { Pepsin; } \\
\text { organic acids; } \mathrm{HCl}\end{array}$ & & \\
\hline \multirow{3}{*}{$\begin{array}{l}\text { Hettiarachchi et al. } 2003 \\
\text { PBET-GI [59] }\end{array}$} & \multirow{3}{*}{\multicolumn{2}{|c|}{$\begin{array}{l}\text { Joplin soil treated or not } \\
\text { with } M n \text {, P, or CRYP }(n=15)\end{array}$}} & $1 / 100 \mathrm{~g} \cdot \mathrm{mL}^{-1}$ & 1 h@ $@$ pH 6.5 & $\begin{array}{l}\text { - In vivo point estimate } \mathrm{RBA} \text { in rats (Y-axis) correlated to } \\
\text { in vitro results ( } \mathrm{X} \text {-axis) }\end{array}$ \\
\hline & & & \multirow[t]{2}{*}{$\begin{array}{l}1 \text { h @ pH } 2.0 \text { Pepsin; } \\
\text { organic acids; } \mathrm{HCl}\end{array}$} & \multirow[t]{2}{*}{$\mathrm{NaHCO}_{3}$; pancreatin; bile } & G phase: $R^{2}=0.95$, intercept 11 , slope 0.82 \\
\hline & & & & & I phase: $R^{2}=0.77$, intercept 12 , slope 1.87 \\
\hline \multirow[t]{4}{*}{$\begin{array}{l}\text { Schroder et al. } 2004 \\
\text { IVG [70] }\end{array}$} & \multirow{4}{*}{\multicolumn{2}{|c|}{18 soils (EPA Region VIII) }} & \multirow{4}{*}{$\begin{array}{l}\text { 1/150 g.mL } \mathrm{mL}^{-1} \\
1 \mathrm{~h} @ \mathrm{pH} 1.8 \mathrm{Pepsin} ; \\
\mathrm{NaCl} ; \mathrm{HCl}\end{array}$} & \multirow{4}{*}{$\begin{array}{l}1 \mathrm{~h} @ \mathrm{pH} 5.5 \\
\text { Pancreatin; bile; } \mathrm{NaHCO}_{3} \text {; } \\
\text { decanol }\end{array}$} & $\begin{array}{l}\text { - In vivo blood RBA (X-axis) in piglets correlated } \\
(p<0.001) \text { to in vitro data }(Y \text {-axis })^{t} \text { : }\end{array}$ \\
\hline & & & & & - $G(R=0.93)$ \& I ( $R=0.80)$ results, with dough \\
\hline & & & & & - $\mathrm{G}$ results no dough ( $\mathrm{R}=0.89$ ) \\
\hline & & & & & $\begin{array}{l}\text { - Best correlation for } G \text { phase with dough: } R^{2}=0.86, n=18 \text {, } \\
\text { intercept } 2.97 \text {, slope } 0.39\end{array}$ \\
\hline \multirow{2}{*}{$\begin{array}{l}\text { Marschner et al. } 2006 \\
\text { IVG [62] }\end{array}$} & \multirow{2}{*}{\multicolumn{2}{|c|}{$\begin{array}{l}5 \text { soils, with or without } \\
\text { milk powder }\end{array}$}} & $1 / 40 \mathrm{~g} \cdot \mathrm{mL}^{-1}$ & $6 \mathrm{~h} @ \mathrm{pH} 7.5$ & \multirow{2}{*}{$\begin{array}{l}\text { - Absence of correlation between in vivo bioavailability in } \\
\text { piglets and in vitro results }\end{array}$} \\
\hline & & & $\begin{array}{l}2 \mathrm{~h} @ \mathrm{pH} 2.0 \text { Pepsin; } \\
\mathrm{NaCl} ; \mathrm{HCl}\end{array}$ & $\begin{array}{l}\mathrm{NaHCO}_{3} \text { trypsin; bile; } \\
\text { pancreatin; urea; inorganics }\end{array}$ & \\
\hline \multirow[t]{3}{*}{$\begin{array}{l}\text { Oomen et al. } 2006 \\
\text { RIVM [86] }\end{array}$} & \multirow[t]{3}{*}{$\begin{array}{l}11 \text { soils or soil-like material } \\
\text { (EPA Region VIII) }\end{array}$} & 5 min @ pH 6.5 & $1 / 37.5$ or $1 / 375 \mathrm{~g} \cdot \mathrm{mL}^{-1}$ & 2 h @ pH 5.5-6.5 & $\begin{array}{l}\text { - In vivo point estimates in piglets ( } X \text {-axis) correlated } \\
\text { to relative in vitro fasted model results ( } Y \text {-axis): }\end{array}$ \\
\hline & & & $2 \mathrm{~h} @ \mathrm{pH} 1.0-2.0$ & \multirow{2}{*}{$\begin{array}{l}\text { (in)organics, pancreatin, } \\
\text { bile, } \mathrm{BSA} \text {, lipase, } \mathrm{CaCl}_{2}\end{array}$} & G phase: $R^{2}=0.68-0.79$, intercept 0 , slope $0.79-1.08$ \\
\hline & & (in)organics, mucin, & (in)organics, pepsin, & & I phase: $R^{2}=0.66-0.81$, intercept 0 , slope 0.69-1.16 \\
\hline
\end{tabular}


Table 4 In vitro procedures applied to $\mathrm{Pb}$ particles and compared with in vivo data for subsequent calibration (2 pages) (Continued)

\begin{tabular}{lll}
\hline Drexler and Brattin 2007; 19 soil-like materials from & $1 / 100 \mathrm{~g}^{-\mathrm{mL}^{-1}}$ \\
USEPA 2007 & EPA region VIII, & $1 \mathrm{~h} \mathrm{@} \mathrm{pH} 1.5$ \\
RBALP [43,84] & & $\mathrm{Glycine} ; \mathrm{HCl}$
\end{tabular}

\section{Bannon et al. 2009}

RBALP [64]

8 small arms range soils

\section{Caboche 2009 Denys}

\section{et al. 2012}

UBM $[65,66]$

14 mining and smelting soils

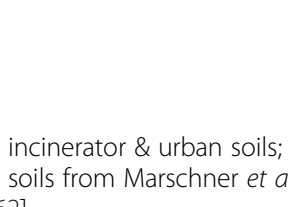

[62]

\section{Juhasz et al. 2009}

SBRC [67]

\section{Wragg et al. 2011}

UBM [95]

12 soils (mining, composite,
phosphate-treated), 1 dust

5 min @ pH 6.5

(in)organics, mucin,

Glycine; $\mathrm{HCl}$

\section{organics, mucin,}

uric acid, alpha-amylase

mucin, BSA 1.2-1.4 uric acid, alpha-amylase

1/100 g.mL ${ }^{-1} 1$ h @ pH 1.5

1/37.5 g.mL $\mathrm{mL}^{-1} 1 \mathrm{~h} @ \mathrm{pH} \quad 4 \mathrm{~h} @ \mathrm{pH}$ 5.8-6.8

(in)organics, pancreatin, bile

BSA, lipase, $\mathrm{CaCl}_{2}$

(in)organics, pepsin,

1/100 g.mL $\quad 4$ h @ pH 6.5

1 h@pH 1.5 Glycine, $\mathrm{HCl}$ NaOH, pancreatin, bile

\section{1/100 g.mL $\mathrm{L}^{-1} 2 \mathrm{~h} @ \mathrm{pH}$}

(in)organics, pepsin mucin, BSA

1/100 g.mL $\mathrm{mL}^{-1} 1 \mathrm{~h} @ \mathrm{pH}$

1.5 Glycine, $\mathrm{HCl}$

2 soils impacted from

variety of $\mathrm{Pb}$ sources

12 soils impacted from a
variety of $\mathrm{Pb}$ sources
$1 / 100 \mathrm{~g} \cdot \mathrm{mL}^{-1} 1 \mathrm{~h} @ \mathrm{pH}$
$1.5 \mathrm{Glycine}$
$4 \mathrm{~h} @ \mathrm{pH} 6.5 \mathrm{NaOH}$

pancreatin, bile
- In vivo RBA point estimates in piglets (Y-axis)

correlated to in vitro results ( $X$-axis) : weighted

$R^{2}=0.924, n=19$, intercept -0.028 , slope $0.878, p<0.001$

- Extensive QA/QC protocol and statistical analyses

- Precision $7 \%$ within samples, and $4-6 \%$ within laboratories (round robin testing)

- In vivo point estimates on piglets: $108^{ \pm 18} \%$ - In vitro results: $83^{ \pm 1}-100^{ \pm 3} \%$

- In vivo kidney RBA in piglets (X-axis) correlated to in vitro results adjusted by $\mathrm{PbAc}$ solubility in the and I phases (Y-axis):

G phase: $R^{2}=0.93$, intercept 1.10, slope $1.86, p<0.0$

I phase: $R^{2}=0.89$, intercept 1.09, slope 1.09, $\mathrm{p}<0.01$

- In vivo blood RBA in piglets (Y-axis) correlated

to relative in vitro data for the I phase

$\left(X\right.$-axis): $R^{2}=0.53$, intercept 1.98 , slope 0.58

(urban \& incinerator soils)

$R^{2}=0.47$, intercept 29.5 , slope 0.42

(soils from Marschner et al., 2006 study)

- In vivo RBA in piglets (X-axis) correlated to in vitro results adjusted by PbAc solubility in the $\mathrm{G}$ and I phases (Y-axis):

$G$ phase: $R^{2}=0.61$, slope 0.78 , median RSD $4 \%$ within samples, $33 \%$ within laboratories

I phase: $R^{2}=0.57$, slope 0.38 , median RSD $15 \%$ within samples, $81 \%$ within laboratories

- In vivo blood RBA in mice (X-axis) correlated to relative in vitro data ( $Y$-axis):

$R^{2}=0.78$, intercept 30.207, slope 0.69

- In vivo blood RBA in mice (X-axis) correlated to relative in vitro data (Y-axis):

$R^{2}=0.88$, intercept -7.02 , slope 1.06 (SBRC, I phase results)

SBRC [68]

IVBA-in vitro bioaccessibility; RBA-relative bioavailability; G-gastric; l-intestinal; RSD-relative standard deviation; " relationship with corrected EPA in vivo data from [84]: ${ }^{\dagger}$ in vitro-in vivo relationship not performed with EPA corrected data (in vivo bioavailability or bulk Pb concentrations). 
protocol, and round robin testing, this test stands out as a reference for application to other test materials. However, as underlined by the USEPA and Juhasz et al., although the substrates used for calibrating this procedure were numerous and originated from various sources, they do not represent the variety of $\mathrm{Pb}$ particles that exist in the environment. Also, they are made up of a significant number of substrates at mining sites for which $\mathrm{Pb}$ dissolution is limited during the gastric phase $[43,67]$. Therefore, the RBALP IVIVC may not hold for any other test material. Specifically, the RBALP applied to substrates containing more soluble forms of $\mathrm{Pb}$ than those found on mine sites, which partially precipitate/ react during the intestinal phase, may overestimate $\mathrm{Pb}$ bioavailability [67]. Finally, results performed on soils following remediation with phosphates showed a better IVIVC with IVBA results performed at $\mathrm{pH} 2.5$, suggesting that the RBALP would give more valuable results at $\mathrm{pH} 2.5$ for evaluating soil remediation effectiveness $[110,111]$.

To respond to these concerns, Juhasz et al. added an intestinal phase to the RBALP and compared the results obtained for the gastric and intestinal phases to in vivo bioavailability results on juvenile swine [67]. The SBRC intestinal test simulates a gastric phase identical to that of the RBALP, except that the agitation is performed at $40 \mathrm{rpm}$ and the filtration on $0.2 \mu \mathrm{m}$ filters, and then a 4-h intestinal phase is simulated at $\mathrm{pH} 6.5$ with the addition of $\mathrm{NaOH}$, bile, and pancreatin. In order to take into account precipitation reactions occurring during the intestinal phase and better relate intestinal IVBA to in vivo results, a relative intestinal IVBA was calculated. This was adjusted with the solubility of PbAc at $\mathrm{pH} 6.5$ in the synthetic fluid, which was estimated at about $10-20 \%$, as compared to $100 \%$ during the gastric phase at $\mathrm{pH} 1.5$ (Equation 7). The application of an intestinal $\mathrm{pH}$ of 6.5 was justified by the fact that PbAc solubility was quite stable between 6.0 and 7.0, making the results more robust.

$$
\text { Relative } P b I V B A=\frac{\frac{\text { in vitro } P b_{T M}}{\text { total extractable } P b_{T M}}}{\frac{\text { in vitro } P b_{P b A c}}{\text { total } P b_{P b A c}}} .
$$

Gastric IVBA and absolute intestinal IVBA were poorly correlated to in vivo data for the five soils tested, while relative intestinal IVBA was satisfactorily correlated $\left(R^{2}=0.53\right)$. Although based on a weak fit $\left(R^{2}=\right.$ 0.12 ), and on few test materials, the authors state that the slightly negative Pearson correlation coefficient observed for the gastric phase may indicate an overestimation of the gastric phase estimates for some $\mathrm{Pb}$ forms. Applied to the same soils tested in the Marschner et al. study [62], relative intestinal IVBA estimates were well correlated to blood RBA on piglets, unlike the IVG results obtained by Marschner et al. [67]. This suggests that the calculation of relative bioaccessibility is a better RBA predictor. Interestingly, Smith et al. tested soils with a wide range of bioavailability (10-83\%) and report excellent correlations between in vivo mouse data and both the RBALP test and the SBRC-intestinal test (Table 4) [68]. The slightly lower correlation obtained using the RBALP is explained by the overprediction of the RBA using this test for some soil types. This overprediction occurs because the presence of iron reduces the intestinal estimates, but not the gastric estimates, and so, the iron soil results correlated better using the SBRC-intestinal test [68]. It should be noted, however, that these conclusions were based on a comparison with mouse in vivo data, which is a less adequate animal model than the juvenile swine model. The IVIVC was then applied to the SBRC relative bioaccessibility results for thirty-one peri-urban soils, and compared to bioavailability predictions using the USEPA regression equation [43] on the SBRC results for the gastric phase. The bioavailability predictions were in agreement for shooting range soils, however different predictions were found for soils with high iron content, incinerator soils, historical fill soils, gasworks soils, and gossan soils (Fe-oxide rich soils). Overall, the RBALP relationships applied to the SBRC gastric results yielded more conservative bioavailability predictions than when the SBRC relationships were applied to the relative intestinal results [112]. This suggests that the addition of an intestinal phase to the RBALP, along with the use of relative bioaccessibility instead of absolute bioaccessibility, may yield bioaccessibility estimates that are closer to actual bioavailability results for some soil matrices. Nonetheless, as emphasized previously, additional inter-laboratory testing, statistical analysis, and further testing on juvenile swine $(\mathrm{N}=5)$ would be desirable to reinforce and standardize the SBRC-intestinal test, since, unlike the RBALP, this procedure has not yet been validated. We conclude that, while some refinements could be added to the RBALP, this test is the one that has been more thoroughly validated, and therefore is the most reliable.

\section{RIVM and UBM procedures}

The RIVM digestion model includes five minutes of simulated contact with saliva, followed by gastric and intestinal phases (two hours each) with end-over-end rotation at about $55 \mathrm{rpm}$ in the presence of complex fluids. Simulation of the salivary phase is not generally added to in vitro models, because of the relatively short duration and neutral $\mathrm{pH}$ of this step. However, this step may be relevant when food is added, which is considered in the RIVM. For the test performed in the presence of food (macaroni, infant formula), adjustments are made in $\mathrm{pH}$ and fluid compositions to represent 'stimulated' 
conditions. Chyme $\mathrm{pH}$ is adjusted to 5.5-6.5 using $\mathrm{NaHCO}_{3}$ (Table 4). As for the RBALP, the test procedure is rigorously controlled for $\mathrm{pH}: 2.0$ for the gastric phase, and 6.5 for the intestinal phase. Extraction is performed by centrifugation at $3,000 \mathrm{~g}$ and the pellet is kept for analysis and mass balance [82,86,87]. Bioaccessibility results for the fasting case were adjusted to $\mathrm{PbAc}$ solubility during the intestinal phase (relative IVBA) and compared to the USEPA data on juvenile swine on eleven soil-like materials. The relationship found was significant for the two S/L ratios tested (1/37.5 and 1/375 g. $\mathrm{mL}^{-1}$ ), for either the gastric or the intestinal phase [86]. The test was further applied in other studies [96,103]. Nonetheless, calibration of the RIVM was performed with bioavailability data from soils used for the RBALP calibration. It would be desirable to test the relationship with soils from more widely varied sources to verify this calibration.

The Unified BARGE Method (UBM) was developed by the Bioaccessibility Research Group Europe (BARGE) with the aim of selecting and standardizing a common procedure for bioaccessibility testing, for several trace elements ( $\mathrm{Pb}$, arsenic, cadmium, and antimony). In the UBM, which is similar overall to the RIVM, the retention time of the gastric phase is reduced to $1 \mathrm{~h}$, and it is increased to $4 \mathrm{~h}$ for the intestinal phase [86]. IVBA results obtained with this approach for $\mathrm{Pb}$ were compared to in vivo RBA on juvenile swine for fourteen mining and smelting soils. Gastric and intestinal bioaccessibility showed strong IVIVC for $\mathrm{Pb}$, arsenic and cadmium (Table 4) $[65,66]$. Therefore, the UBM could be applied for estimating the $\mathrm{Pb}$, cadmium, and arsenic RBA for a single test material, and at the same time, which is an important advantage. This again suggests that the addition of the intestinal phase can be successfully linked to RBA results using the relative IVBA. However, in another study, results from the intestinal phase were not considered reliable for 13 other test materials, and those results did not meet any of the criteria set for validation (Table 4) [95]. Denys et al. concluded that the stomach phase of the UBM, carefully controlled for $\mathrm{pH}$, produces IVBA results that are very comparable to juvenile swine RBA values [66]. Therefore, the addition of the intestinal phase, although possible, does not appear essential, and also complicates the test and its validation. The gastric phase of the test was validated for $\mathrm{Pb}$, cadmium, and arsenic, and showed a significant IVIVC and reliable repeatability of the results [66]. An inter-laboratory trial was not able to fully validate the test for good reproducibility (between laboratories) for $\mathrm{Pb}$. Nonetheless results suggest that a tight control of the gastric $\mathrm{pH}$ during extractions would allow for a complete validation [95].

The simulation of both the gastric and the intestinal phase greatly impacts the estimates of $\mathrm{Pb}$ bioaccessibility.
Bruce et al. measured a bioaccessibility of $47 \%$ for the mine wastes at the end of the gastric phase, and these values dropped to $7 \%$ at the end of the intestinal phase [94]. The same range of decrease in bioaccessibility was observed in other studies [67,113-115]. Results using PbISE and DPASV in chyme following GI in vitro digestion showed that the free $\mathrm{Pb}^{2+}$ is indeed negligible, and that most of the $\mathrm{Pb}$ was present as $\mathrm{Pb}$-phosphate and $\mathrm{Pb}$-bile complexes in dynamic equilibrium with solubilized $\mathrm{Pb}$ [85]. This solubilized $\mathrm{Pb}$ is largely removed from the solution by precipitation or adsorption on non-digested and compatible particles $[67,74]$. These observations show that $\mathrm{Pb}$ bioaccessibility could be overestimated if limited to the gastric phase. However, significant experimental challenges arise from the precipitation reactions, the gradual $\mathrm{pH}$ increase and parallel absorption, the eventual adsorption of soluble $\mathrm{Pb}$ on non-digested particles, and the increase of labile complexes that are difficult to maintain in equilibrium in the intestinal chyme $[74,85]$. Precipitation conditions may not be as well simulated in a closed system as in the gut, which is a thermodynamically open system [52], but spiking and correction for recovery could account for these losses. Comparison of $\mathrm{Pb}$ speciation by XANES after the gastric and intestinal phases has clearly shown the dominance of solubilized $\mathrm{Pb}$ after the gastric phase and the importance of the presence of coprecipitation with amorphous iron in soils containing iron oxyhydroxides [68]. To address some of these concerns, intestinal bioaccessibility can be adjusted relative to estimates of a soluble $\mathrm{Pb}$ form (e.g. PbAc), at a 'stable' intestinal $\mathrm{pH}$ (6.0-7.0) (Figure 3) [67]. With this adjustment, relative bioaccessibility estimates from the intestinal phase are slightly lower than the gastric bioaccessibility estimates, and seem to better relate to in vivo data [67]. However, results of tests simulating the gastric phase only are still more reliable, given that these tests are fully validated. Also, considering the difficulties associated with adding an intestinal phase, and although significant IVIVC can be obtained with intestinal results, full validation of the test with good repeatability and reproducibility would be quite challenging. To refine intestinal in vitro testing, further knowledge on the exact sites where $\mathrm{Pb}$ absorption takes place along the gut and at which $\mathrm{pH}$ would be necessary, so that the critical steps of the intestinal phase could be better reproduced.

In conclusion, the RBALP appears to be the best test yet devised for estimating the potential for childhood exposure to multiple $\mathrm{Pb}$ sources, even though it is not fully physiologically based. This test is the most suitable for the cost effective testing of multiple sources of $\mathrm{Pb}$ particles. It is likely to overestimate bioavailability for some test materials, and will produce a conservative IVBA estimate for these materials. However, the test is relatively 
simple and quick, and has been validated with in vivo data on the best suited animal surrogate for childhood digestive conditions. Moreover, it is the only procedure that has been validated through a complete statistical analysis and round robin testing. Consequently, the RBALP is standardized and can be applied in many laboratories on multiple test materials. The gastric phase of the UBM, which is currently in the process of being fully validated, is a pertinent alternative to the RBALP, as it tests the IVBA of three elements in the same procedure.

\section{Tests not compared with in vivo data}

Several in vitro tests that have not been compared with in vivo data have been proposed. These tests are important, since they may be validated in the future or be useful for studying factors influencing $\mathrm{Pb}$ bioaccessibility and bioavailability. Table 5 and Table 6 summarize the various parameters applied in some of these tests either not physiologically based (Table 5) or physiologically based (Table 6).

Procedures that are not physiologically based (Table 5) include a large number of batch acid extractions using dilute $\mathrm{HCl}$ performed at various $\mathrm{S} / \mathrm{L}$ ratios, durations, and $\mathrm{pH}$. Since 1994, $\mathrm{HCl}$ extraction has been a standard method for assessing the toxicity of toys used to establish the European Standard on the Safety of Toys. The toy material is reduced to a particle size $<500 \mu \mathrm{m}$ and added to an $\mathrm{HCl}$ solution using a $1 / 50$ g.mL $\mathrm{mL}^{-1}$ ratio $(\mathrm{pH}$ $1.5 ; 37^{\circ} \mathrm{C} ; 2 \mathrm{~h}$ ) $[50,129]$. As pointed out by Le Bot et al. [122], such tests may be helpful in preventing $\mathrm{Pb}$ poisoning. In fact, $\mathrm{Pb}$ leached during $\mathrm{HCl}$ extractions simulating stomach conditions may provide a more relevant indication of potentially bioavailable $\mathrm{Pb}$ than standard total $\mathrm{Pb}$ extractable measurements on wastes and solids. Some sources could have high values of total extractable $\mathrm{Pb}$ even though it is poorly soluble in the stomach, or, inversely, they could impair the interpretation of BLLs and environmental $\mathrm{Pb}$ levels.

Among the physiologically based models presented in Table 6, many are modifications of the PBET, IVG, or RIVM procedure. The German method, E DIN 19738 [DIN] mimics gastrointestinal digestion for infants/children, in a fasting case or a fed state, through the addition of whole milk powder. Gastric fluids are composed of a mixture of pepsin, mucin, and $\mathrm{HCl}$. Intestinal fluids contain bile, trypsin, pancreatin, and phosphate buffer. The gastric phase takes place at $\mathrm{pH} 2$ over 2 hours, and a $\mathrm{pH}$ of 7.5 is applied to the intestinal phase over 6 hours. Extraction is achieved by a two phase centrifugation at 7,000 g, decantation, and analysis of the supernatant [82,87]. Although somewhat laborious, DIN appears to be a relevant method, as there is a need for a test with whole milk powder for infants exposed to $\mathrm{Pb}$ particles in drinking water via baby feeding bottles.

The TIM, SHIME, and flow-through methods using online extractions are dynamic, physiologically based tests $[87,130,131]$. The TIM model (or TNO GI model) mimics the contact with saliva and further GI digestion by the progressive addition of fluids, the progressive adjustment of $\mathrm{pH}$, and the simulation of peristaltic contractions. Gastric $\mathrm{pH}$ and retention times are adjusted differently if the simulation is aimed at representing a fed state $(\mathrm{pH}$ decreases gradually from 5 to 2 over 90 $\mathrm{min}$ ) or a fasting state ( $\mathrm{pH}$ decreases gradually from 4.5 to 1.8 over $40 \mathrm{~min}$ ). Then, intestinal fluids are added at $1 \mathrm{~mL} / \mathrm{min}$ to increase the $\mathrm{pH}$ from 6.5 to 7.2 , at which point ultra-filtration is performed. This model has been validated with in vivo dissolution profiles of drugs with or without food; however, it was not calibrated for $\mathrm{Pb}$ particles $[82,86,87]$. The SHIME (Simulator of Human Intestinal Microbial Ecosystem of Infants) model, developed in Belgium, simulates $3 \mathrm{~h}$ gastric and $5 \mathrm{~h}$ intestinal digestion in the same reactor (150 rpm). Gradients of $\mathrm{pH}$ can be applied if a series of reactors is used (dynamic model), and a phase including a mixed microbial community can be added to the model $[82,132]$. Constant stomach retention times are applied for fasting conditions $(\mathrm{pH} \sim 2.0)$ and fed conditions $(\mathrm{pH} \sim 4.0)$ [87]. Centrifugation at $7,000 \mathrm{~g}$ is conducted and the supernatant is analyzed. The pellet is then digested to mass balance [82]. However, these procedures cannot be used routinely to measure $\mathrm{Pb}$ bioaccessibility on $\mathrm{Pb}$ particles since they take too long to perform and are highly complex. Nevertheless, it appears that they could be highly useful for studying specific factors affecting $\mathrm{Pb}$ bioavailability that have been poorly studied up to now, such as the effect of bacteria.

\section{Bioavailability/bioaccessibility of $\mathrm{Pb}$ particles in relation to $\mathrm{Pb}$ speciation, particle size, and surrounding matrix} Physical and chemical aspects of $\mathrm{Pb}$ particles are major factors influencing the dissolution of particles containing $\mathrm{Pb}$. Table 7 summarizes the IVBA results for calibrated procedures, and shows that bioavailability and bioaccessibility results vary widely with the test material: from 1.7$6 \%$ for galena to $100 \%$ for shooting range soil, which is in agreement with the in vivo swine data $[42,64,68,84,86]$, and from 1.5 to $100 \%$ for tap water particles [29]. Pb was also found to be highly bioaccessible in NIST Paint (75-86\%), which is in agreement with previous epidemiological studies referenced in Mushak [30]. In addition, $\mathrm{Pb}$ is generally highly bioaccessible in smelter soils, with about $68-69 \%$ for some Omaha community soils, and about $70-85 \%$ for the Herculaneum smelter $[61,63]$, and 34-90\% for ten smelting soils from northern France [65]. However, variability in the bioavailability and bioaccessibility 
Table 5 Examples of variants of non-physiologically-based in vitro procedures (not calibrated) applied to $\mathrm{Pb}$ particles

\begin{tabular}{|c|c|c|c|c|c|c|c|c|}
\hline \multicolumn{4}{|c|}{ GENERAL } & \multicolumn{3}{|c|}{ GASTRIC } & \multicolumn{2}{|c|}{ INTESTINAL } \\
\hline Reference & Mixing & $\mathrm{T}^{\circ} \mathrm{C}$ & Extraction & $\mathrm{S} / \mathrm{L}\left(\mathrm{g} \cdot \mathrm{mL}^{-1}\right)$ & Time, pH & Fluid & Time, pH & Fluid \\
\hline Sheppard et al. 1995 [116] & & & Filtration $0.5 \mu \mathrm{m}$ & $1 / 167$ & 24 h, pH 2.0 & $\mathrm{HCl}$ & & \\
\hline Gasser et al. 1996 [91] & Stirred-flow reactor & $24^{\circ} \mathrm{C}$ & Filtration $0.22 \mu \mathrm{m}$ & $1 / 100$ & $1 \mathrm{~h}, \mathrm{pH} 1.0$ to 3.0 & $\mathrm{HCl}$, ammonium acetate & & \\
\hline Gasser et al. 1996 [91] & Horizontal shaker & $24^{\circ} \mathrm{C}$ & $\begin{array}{l}\text { Centrifugation } \\
\text { (400 RCF; } 10 \mathrm{~min} \text { ) }\end{array}$ & $1 / 200$ & $1 \mathrm{~h}, \mathrm{pH} 1.0$ & $\mathrm{HCl}$ & & \\
\hline Rieuwerts et al. 2000 [117] & $\begin{array}{l}\text { Inversion by hand } 5 \text { times } \\
\text { at } \mathrm{t}=1 \mathrm{~h}\end{array}$ & Ambient & $\begin{array}{l}\text { Centrifugation } \\
(2,000 \text { rpm; } 2 \text { min) }\end{array}$ & $1 / 100$ & $2 \mathrm{~h}, \mathrm{pH} 1.2$ & $\mathrm{HCl}$ & & \\
\hline Yang et al. 2001 [118] & Rotation 30 rpm & $37^{\circ} \mathrm{C}$ & Filtration $0.2 \mu \mathrm{m}$ & $1 / 100$ & $1 \mathrm{~h}, \mathrm{pH} 2-2.5$ & $\mathrm{HCl}$ & & \\
\hline Mercier et al. 2002 [119] & $\begin{array}{l}\text { End-over-end } 30 \mathrm{rpm} \text {, at } \\
20 \text { min intervals, for } 20 \mathrm{~min}\end{array}$ & $35-39^{\circ} \mathrm{C}$ & Decantation, filtration & $1 / 22$ & $\begin{array}{l}160 \pm 10 \mathrm{~min} \\
\mathrm{pH} 6.0 \text { to } 2.0\end{array}$ & $\mathrm{HCl}$, acetic acid & & \\
\hline Yang et al. 2002 [120] & Rotation 30 rpm & $37^{\circ} \mathrm{C}$ & Filtration $0.2 \mu \mathrm{m}$ & $1 / 100$ & $1 \mathrm{~h}, \mathrm{pH} 2.0$ & $\mathrm{HCl}$ & & \\
\hline $\begin{array}{l}\text { Scheckel and Ryan } 2003 \\
\text { [93] }\end{array}$ & Continuous stirring & $37^{\circ} \mathrm{C}$ & Filtration $0.45 \mu \mathrm{m}$ & $1 / 160$ & $1 \mathrm{~h}, \mathrm{pH} 2.0$ & $\mathrm{HCl}$ & $5 \mathrm{~h}, \mathrm{pH} 7.0$ & \\
\hline Yang et al. 2003 [83] & End-over-end,30 rpm & $37^{\circ} \mathrm{C}$ & $\begin{array}{l}\text { Decantation, filtration } \\
0.45 \mu \mathrm{m}\end{array}$ & $\begin{array}{l}1 / 40 \text { and } \\
1 / 100\end{array}$ & $1 \mathrm{~h}, \mathrm{pH} 1.5$ to 4.0 & $\mathrm{HCl}$, glycine & $3 \mathrm{~h}, \mathrm{pH} 7.0$ & $\mathrm{NaHCO}_{3}$ \\
\hline Beak et al. 2006 [121] & $\begin{array}{l}\text { Variable speed mixer } \\
(150 \mathrm{rpm}) ; 2 \mathrm{~mL} / \mathrm{min} \mathrm{Ar}\end{array}$ & $37^{\circ} \mathrm{C}$ & Filtration $0.45 \mu \mathrm{m}$ & $1 / 167$ & $2 \mathrm{~h}, \mathrm{pH} 1.8$ & $\mathrm{HCl}$ & $4 \mathrm{~h}, \mathrm{pH} 7.0$ & $\mathrm{NaOH}$ \\
\hline $\begin{array}{l}\text { Turner and Simmonds } 2006 \\
\text { [98] }\end{array}$ & & Ambient & & $1 / 100$ & Overnight & $\mathrm{HCl}$, pepsin & & \\
\hline $\begin{array}{l}\text { Bosso and Enzweiler } 2008 \\
\text { [107] }\end{array}$ & Orbital, 100 rpm & $37^{\circ} \mathrm{C}$ & $\begin{array}{l}\text { Centrifugation } \\
(5,000 \text { rpm; } 20 \text { min) }\end{array}$ & $1 / 100$ & $1 \mathrm{~h}, \mathrm{pH} 1.5$ & $\begin{array}{l}\mathrm{HCl} \text {, glycine } \mathrm{OR} \mathrm{HCl} \text {, } \\
\text { pepsin, } \mathrm{NaCl}\end{array}$ & $2 \mathrm{~h}, \mathrm{pH} 7.0$ & $\mathrm{NaHCO}_{3}$ \\
\hline $\begin{array}{l}\text { Le Bot et al. 2010, } 2011 \\
{[122,123]}\end{array}$ & Ultrasonication & $37^{\circ} \mathrm{C}$ & Filtration $0.45 \mu \mathrm{m}$ & & $1 \mathrm{~h}, \mathrm{pH} 1.5$ & $\mathrm{HCl}, 0.75-1.4 \%$ diluted & & \\
\hline $\begin{array}{l}\text { Rasmussen et al. } 2011 \\
{[124]}\end{array}$ & & $37.5^{\circ} \mathrm{C}$ & $\begin{array}{l}\text { Centrifugation } \\
(5,000 \mathrm{~g}, \leq 10 \mathrm{~min})\end{array}$ & $1 / 2000$ & $2 \mathrm{~h}, \mathrm{pH} 1.5$ & $\mathrm{HCl}$ & & \\
\hline
\end{tabular}


Table 6 Examples of variants of physiologically based in vitro procedures (not calibrated) applied to $\mathrm{Pb}$ particles (2 pages)

\begin{tabular}{|c|c|c|c|c|c|c|c|c|c|}
\hline \multicolumn{3}{|c|}{ GENERAL } & \multicolumn{2}{|r|}{ ORAL } & \multicolumn{3}{|c|}{ GASTRIC } & \multicolumn{2}{|r|}{ INTESTINAL } \\
\hline References & Mixing & Extraction & $\begin{array}{l}\text { Time, } \\
\mathrm{pH}\end{array}$ & Fluid & $\begin{array}{l}\mathrm{S} / \mathrm{L} \\
\left(\mathrm{g} \cdot \mathrm{mL}^{-1}\right)\end{array}$ & Time, pH & Fluid & Time, pH & Fluid \\
\hline $\begin{array}{l}\text { Sheppard et al. } 1995 \\
\text { [116] }\end{array}$ & & $\begin{array}{l}\text { Centrifugation, } \\
\text { filtration } 0.2 \mu \mathrm{m}\end{array}$ & & & & $4 \mathrm{~h}, \mathrm{pH} 2.0$ & $\mathrm{NaCl} ;$ pepsin; $\mathrm{HCl}$ & 18 h, pH 7.5 & $\begin{array}{l}\mathrm{NaHCO}_{3} ; \mathrm{NaCl} \text {; bile; } \\
\text { pancreatin; a-amylase }\end{array}$ \\
\hline $\begin{array}{l}\text { Berti and Cunningham } \\
1997[125]\end{array}$ & Stir bar & & & & $1 / 100$ & $1 \mathrm{~h}, \mathrm{pH} 2.5$ & $\begin{array}{l}\text { Pepsin; organic } \\
\text { acids; } \mathrm{HCl}\end{array}$ & $2 \mathrm{~h}, \mathrm{pH} 7.0$ & $\begin{array}{l}\mathrm{NaHCO}_{3} ; \text { pancreatin; } \\
\text { bile }\end{array}$ \\
\hline Davis et al. 1997 [126] & $\begin{array}{l}\text { Wrist action } \\
\text { shaker }\end{array}$ & $\begin{array}{l}\text { Centrifugation } \\
(2,100 \mathrm{~g} ; 25 \mathrm{~min})\end{array}$ & & & $1 / 10$ & $2 \mathrm{~h}, \mathrm{pH} 1.3$ & $\begin{array}{l}\text { Pepsin; organic } \\
\text { acids; } \mathrm{HCl}\end{array}$ & $2 \mathrm{~h}, \mathrm{pH} 7.0$ & $\begin{array}{l}\mathrm{NaHCO}_{3} ; \text { pancreatin; } \\
\text { bile }\end{array}$ \\
\hline Hamel et al. 1998 [92] & $\begin{array}{l}\text { Shaking } \\
\text { water bath }\end{array}$ & $\begin{array}{l}\text { Centrifugation } \\
(1,380 \mathrm{~g} ; 10 \mathrm{~min})\end{array}$ & & & $\begin{array}{l}1 / 100 \text { to } \\
1 / 5000\end{array}$ & $2 \mathrm{~h}$ & $\mathrm{NaCl} ;$ pepsin; $\mathrm{HCl}$ & & \\
\hline Hamel et al. 1999 [102] & $\begin{array}{l}\text { Water bath, } \\
90 \mathrm{cyc} / \mathrm{min}\end{array}$ & $\begin{array}{l}\text { Centrifugation } \\
\text { (906 g; } 10 \mathrm{~min}), \\
\text { filtration } 0.45 \mu \mathrm{m}\end{array}$ & $\begin{array}{l}5 \mathrm{~s} \\
\mathrm{pH} 5.5\end{array}$ & $\begin{array}{l}\text { Mucin; urea; } \\
\mathrm{KCl} ; \mathrm{NaCl} ; \\
\mathrm{Na}_{2} \mathrm{HPO}_{4} ; \\
\mathrm{CaCl}_{2} \cdot 4 \mathrm{H}_{2} \mathrm{O}\end{array}$ & $1 / 2160$ & $2 \mathrm{~h}$ & $\mathrm{NaCl}$; pepsin; $\mathrm{HCl}$ & $2 \mathrm{~h}$ & $\mathrm{NaHCO}_{3}$ \\
\hline Oliver et al. 1999 [89] & $\begin{array}{l}\text { Wrist action } \\
\text { shaker }\end{array}$ & Filtration $0.45 \mu \mathrm{m}$ & & & $1 / 10$ & $\begin{array}{l}2 \mathrm{~h}, \mathrm{pH} 1.3 \text { to } \\
3.0\end{array}$ & $\begin{array}{l}\text { Organic acids; } \mathrm{HCl} \text {; } \\
\text { with(out) pepsin }\end{array}$ & 16 h, pH 7.0 & $\begin{array}{l}\mathrm{NaHCO}_{3} \text { with(out) } \\
\text { bile \& pancreatin }\end{array}$ \\
\hline Ellickson et al. 2001 [57] & $\begin{array}{l}\text { Bath set, } \\
90 \mathrm{cyc} / \mathrm{min}\end{array}$ & $\begin{array}{l}\text { Centrifugation } \\
(200 \mathrm{~g} ; 20 \mathrm{~min}) \& \\
(906 \mathrm{~g} ; 15 \mathrm{~min}) ; \\
\mathrm{HNO}_{3}, 48 \mathrm{~h} ; \\
\text { filtration } 0.45 \mu \mathrm{m}\end{array}$ & & $\begin{array}{l}\text { Mucin; urea; } \mathrm{CaCl}_{2} \text {. } \\
\mathrm{H}_{2} \mathrm{O} ; \mathrm{NaCl} ; \mathrm{KCl} ; \\
\mathrm{Na}_{2} \mathrm{HPO}_{4}\end{array}$ & $1 / 2160$ & $2 \mathrm{~h}, \mathrm{pH} 1.4$ & Pepsin; $\mathrm{NaCl} ; \mathrm{HCl}$ & $4 \mathrm{~h}, \mathrm{pH} 6.5$ & $\mathrm{NaHCO}_{3}$ \\
\hline $\begin{array}{l}\text { Oomen et al. 2002, } \\
\text { Van De Wiele et al. } 2007 \\
\text { [82,87]; DIN test }\end{array}$ & $\begin{array}{l}\text { Agitator, } \\
200 \mathrm{rpm}\end{array}$ & $\begin{array}{l}\text { Centrifugation } \\
(7,000 \mathrm{~g} ; 10 \mathrm{~min})\end{array}$ & & & $1 / 50$ & $2 \mathrm{~h}, \mathrm{pH} 2.0$ & HCl; [pepsin; mucin] $]^{*}$ & $6 \mathrm{~h}, \mathrm{pH} 7.5$ & $\begin{array}{l}\text { Phosphate buffer; } \\
\text { [bile; trypsin; } \\
\text { pancreatin] }\end{array}$ \\
\hline $\begin{array}{l}\text { Oomen et al. 2002, } \\
\text { Van De Wiele et al. } 2007 \\
\text { [82,87]; SHIME test }\end{array}$ & $\begin{array}{l}\text { Stirring, } \\
150 \text { rpm }\end{array}$ & $\begin{array}{l}\text { Centrifugation } \\
\text { (7,000 g; } 10 \mathrm{~min})\end{array}$ & & & $\begin{array}{l}1 / 2.5 \text { to } \\
1 / 40\end{array}$ & $\begin{array}{l}3 \mathrm{~h}, \mathrm{pH} 2.0 \\
\text { (fast) or } 4.0 \text { (fed) }\end{array}$ & $\begin{array}{l}\text { Nutrilon plus; pectin; } \\
\text { mucin; cellobiose; } \\
\text { proteose peptone; } \\
\text { starch; glucose }\end{array}$ & 5 h, pH 6.5 & $\begin{array}{l}\mathrm{NaHCO}_{3} ; \text { pancreatin; } \\
\text { bile }\end{array}$ \\
\hline \multirow{2}{*}{$\begin{array}{l}\text { Oomen et al. 2002, } \\
\text { Van De Wiele et al. } 2007 \\
\text { [82,87]; TIM test }\end{array}$} & \multirow[t]{2}{*}{ Peristaltic } & \multirow[t]{2}{*}{ Ultrafiltration } & \multirow[t]{2}{*}{$\begin{array}{l}5 \mathrm{~min}, \\
\mathrm{pH} 5.0\end{array}$} & & & $\begin{array}{l}\text { Fast: } 40 \mathrm{~min}, \mathrm{pH} \\
4.5 \text { to } 1.8\end{array}$ & \multirow[t]{2}{*}{$\begin{array}{l}\text { HCl; lipase; pepsin } \\
0.5 \mathrm{~mL} / \mathrm{min}\end{array}$} & $\begin{array}{l}\text { Fast: } 5.3 \text { h, } \\
\text { pH } 6.5 \text { to } 7.2\end{array}$ & \multirow{2}{*}{$\begin{array}{l}\mathrm{NaHCO}_{3 i} ; \\
\text { pancreatin; bile } \\
1 \mathrm{~mL} / \mathrm{min}\end{array}$} \\
\hline & & & & & & $\begin{array}{l}\text { Fed: } 1.5 \mathrm{~h}, \mathrm{pH} \\
5.0 \text { to } 2.0\end{array}$ & & $\begin{array}{l}\text { Fed: } 4.5 \mathrm{~h}, \mathrm{pH} \\
6.5 \text { to } 7.2\end{array}$ & \\
\hline Yu et al. 2006 [113] & $\begin{array}{l}\text { Water bath, } \\
90 \mathrm{rpm}\end{array}$ & Filtration $0.45 \mu \mathrm{m}$ & & $\begin{array}{l}\text { Mucin; urea; } \\
\mathrm{KH}_{2} \mathrm{PO}_{4} ; \mathrm{CaCl}_{2} \cdot \mathrm{H}_{2} \mathrm{O} ; \\
\mathrm{NaCl}, \mathrm{KCl}\end{array}$ & $1 / 400$ & $2 \mathrm{~h}, \mathrm{pH} 1.4$ & $\mathrm{NaCl} ;$ pepsin; $\mathrm{HCl}$ & $2 \mathrm{~h}, \mathrm{pH} 6.5$ & $\mathrm{NaHCO}_{3}$ \\
\hline Bruce et al. 2007 [94] & $\operatorname{Ar}$ & $\begin{array}{l}\text { Centrifugation } \\
(10,000 \mathrm{~g} ; 15 \mathrm{~min}), \\
\text { filtration } 0.22 \mu \mathrm{m}\end{array}$ & & & $1 / 100$ & $\begin{array}{l}1 \mathrm{~h} \mathrm{pH} 1.3 \text { (fast) } \\
\text { to } 4 \text { (fed) }\end{array}$ & $\begin{array}{l}\text { Pepsin; } \mathrm{HCl} \\
\text { organic acids }\end{array}$ & $3 \mathrm{~h} \mathrm{pH} 7.0$ & $\begin{array}{l}\mathrm{NaHCO}_{3} ; \text { bile; } \\
\text { pancreatin }\end{array}$ \\
\hline
\end{tabular}


Table 6 Examples of variants of physiologically based in vitro procedures (not calibrated) applied to Pb particles ( 2 pages) (Continued)

\begin{tabular}{|c|c|c|c|c|c|c|c|}
\hline Saikat et al. 2007 [104] & & $\begin{array}{l}\text { Centrifugation } \\
(2,100 \mathrm{~g} ; 25 \mathrm{~min})\end{array}$ & $\begin{array}{l}1 / 38- \\
1 / 100\end{array}$ & $\begin{array}{l}1 \mathrm{~h} \mathrm{pH} 1.1 \text { or } \\
2.5\end{array}$ & $\begin{array}{l}\text { Pepsin; organic } \\
\text { acids; } \mathrm{HCl}\end{array}$ & $\begin{array}{l}4 \mathrm{~h}, \mathrm{pH} 5.5 \text { or } \\
7.0\end{array}$ & $\begin{array}{l}\mathrm{NaHCO}_{3} ; \\
\text { pancreatin; bile }\end{array}$ \\
\hline $\begin{array}{l}\text { Triantafyllidou et al. } 2007 \\
\text { [26] }\end{array}$ & $\begin{array}{l}\text { Gentle } \\
\text { mixing }\end{array}$ & No separation & $1 / 16,667$ & $3 \mathrm{~h}, \mathrm{pH} 1.2$ & $\mathrm{NaCl} ;$ pepsin; $\mathrm{HCl}$ & & \\
\hline Turner and Ip 2007 [127] & End-over-end & $\begin{array}{l}\text { Centrifugation } \\
(2,100 \mathrm{~g} ; 10 \mathrm{~min})\end{array}$ & $1 / 200$ & $2 \mathrm{~h}, \mathrm{pH} 2.5$ & $\begin{array}{l}\text { Pepsin; } \mathrm{HCl} ; \mathrm{Na} \text { malate \& } \\
\text { citrate; lactic \& acetic acids }\end{array}$ & $4 \mathrm{~h}, \mathrm{pH} 7.0$ & $\begin{array}{l}\mathrm{NaHCO}_{3} ; \text { bile; } \\
\text { pancreatin }\end{array}$ \\
\hline $\begin{array}{l}\text { Van De Wiele et al. } 2007 \\
\text { [87] }\end{array}$ & $\begin{array}{l}\text { Water rotator } \\
\text { set }\end{array}$ & Filtration $0.45 \mu \mathrm{m}$ & $1 / 100$ & $1 \mathrm{~h} \mathrm{pH} 2.5$ & $\begin{array}{l}\text { Pepsin; } \mathrm{HCl} ; \mathrm{Na} \text { citrate \& } \\
\text { malate; lactate, acetate }\end{array}$ & $4 \mathrm{~h}, \mathrm{pH} 7.0$ & $\begin{array}{l}\mathrm{NaHCO}_{3 ;} \text { bile; } \\
\text { pancreatin }\end{array}$ \\
\hline $\begin{array}{l}\text { Bosso and Enzweiler 2008; } \\
\text { Bosso et al. } 2008[107,114]\end{array}$ & $\begin{array}{l}\text { Slow orbital } \\
+ \text { Ar flux }\end{array}$ & $\begin{array}{l}\text { Centrifugation } \\
\text { (5,000 rpm; } 20 \text { min) }\end{array}$ & $1 / 100$ & $1 \mathrm{~h}, \mathrm{pH} 1.7$ & $\begin{array}{l}\text { Pepsin; HCl; citric, malic, } \\
\text { acetic, \& lactic acids }\end{array}$ & $2 \mathrm{~h}, \mathrm{pH} 7.0$ & $\begin{array}{l}\mathrm{NaHCO}_{3 ;} \text { bile; } \\
\text { pancreatin }\end{array}$ \\
\hline Turner et al. 2009 [128] & $\begin{array}{l}\text { Constant, } \\
\text { lateral }\end{array}$ & $\begin{array}{l}\text { Centrifugation } \\
\text { (2,000 g; } 10 \mathrm{~min})\end{array}$ & $\begin{array}{l}1 / 100-1 / \\
143\end{array}$ & $1 \mathrm{~h}, \mathrm{pH} 2.5$ & $\begin{array}{l}\text { Pepsin; } \mathrm{HCl} \text {; Na malate, } \\
\text { citrate; lactic \& acetic acids }\end{array}$ & $4 \mathrm{~h}, \mathrm{pH} 7.0$ & $\begin{array}{l}\mathrm{NaHCO}_{3} ; \text { bile; } \\
\text { pancreatin }\end{array}$ \\
\hline Sialelli et al. 2010 [115] & $\begin{array}{l}\text { Orbital, } \\
150 \text { rpm }\end{array}$ & & $1 / 100$ & $1 \mathrm{~h}, \mathrm{pH} 1.5$ & $\begin{array}{l}\text { Pepsin; } \mathrm{HCl} ; \mathrm{Na} \text { citrate; malic } \\
\text { \& lactic acids }\end{array}$ & $3.5 \mathrm{~h}, \mathrm{pH} 7.0$ & Pancreatin, $\mathrm{NaHCO}_{3}$ \\
\hline
\end{tabular}


Table 7 Main bioaccessibility results for materials tested using an in vitro procedure calibrated with in vivo data

\begin{tabular}{|c|c|c|}
\hline SUBSTRATE & IVBA\% & REFERENCES \\
\hline Flanders soil & $91 \pm 4$ & \multirow{11}{*}{$\begin{array}{l}{[29,43,60,61,63,64,82,84,109]} \\
\text { RBALP (Gastric) }\end{array}$} \\
\hline Oker 11 soil & $56 \pm 4$ & \\
\hline 47 Omaha community smelter soils, US & 68-69 (average) & \\
\hline \multirow[t]{2}{*}{ HER-2930 smelter soil, US } & $69 \pm 1.5$ (using Dr Drexler's Pb levels) & \\
\hline & $85 \pm 1.1$ (using EPA's average bulk Pb levels) & \\
\hline 17 residential soils, tailings, and slags from mining waste sites, US & $14 \pm 1.7$ to $90 \pm 3.1$ & \\
\hline 1 NIST paint & $75 \pm 3.8$ & \\
\hline 1 Galena & $6 \pm 2.3$ & \\
\hline 8 shooting range soils, US & $83 \pm 1$ to $100 \pm 3$ & \\
\hline $\begin{array}{l}20 \text { soils from the N-S transect, US } \\
\text { (agricultural, grazing land, open range, forested land, residential, desert) }\end{array}$ & 3.7 to 39 & \\
\hline 70 samples of tap water particles & 1.5 to 100 & \\
\hline 9 soils from mining sites* & $3.1 \pm 0.1$ to $99.3 \pm 14.3$ & [86] RIVM (Intestinal) \\
\hline 1 NIST paint* + soil & $86.2 \pm 2.3$ & \\
\hline 1 Galena* & $1.7 \pm 0.2$ & \\
\hline 15 mining soils, France & 9-75 (Intestinal) & {$[65,66,95,133,134]$ UBM } \\
\hline 10 smelting soils, France & 34-90 (Intestinal) & \\
\hline 27 urban topsoils, France & 11-63 (Intestinal) & \\
\hline \multirow{2}{*}{$\begin{array}{l}12 \text { soils (mining, composite, phosphate-treated), } \\
1 \text { dust, from various studies (European and North American) }\end{array}$} & $0.6 \pm 0.1$ to $112.8 \pm 18.5$ (Gastric) & \\
\hline & $0.1 \pm 0.1$ to $89.5 \pm 91.3$ (Intestinal) & \\
\hline 2 urban residential soils, Australia & $20.0 \pm 4.0$ to $26.1 \pm 6.5$ & {$[67,68,112]$ SBRC (Intestinal) } \\
\hline \multirow[t]{2}{*}{3 domestic incinerator soils, Australia } & $11.7 \pm 2.8$ to $22.5 \pm 5.0$ & \\
\hline & $3.2 \pm 2.6$ to $8.5 \pm 0.6^{+}$ & \\
\hline Brushal, Carl-1, Hamburg, and Oker-11 soils ${ }^{\S}$ & $30.7 \pm 6.1$ to $62.9 \pm 11.0$ & \\
\hline \multirow[t]{2}{*}{9 shooting range soils, Australia } & 21.3-102.6 & \\
\hline & $59 \pm 3.7$ to $92 \pm 9.0(3 \text { soils })^{+}$ & \\
\hline \multirow[t]{2}{*}{5 historical fill soils, Australia } & 5.5-26.1 (4 soils) & \\
\hline & 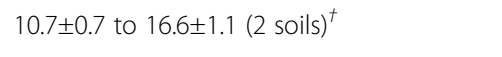 & \\
\hline \multirow[t]{2}{*}{13 mining/smelting soils, Australia } & $11.6-82.5$ & \\
\hline & $31 \pm 18.4$ to $74 \pm 17.3$ (3 soils) $^{+}$ & \\
\hline \multirow[t]{2}{*}{1 gasworks, Australia } & 27.2 & \\
\hline & $27 \pm 1.6^{t}$ & \\
\hline 1 geogenic, Australia & 12.5 & \\
\hline
\end{tabular}

${ }^{*}$ Same test materials as in RBALP studies, $0.06 \mathrm{~g}$; ${ }^{\S}$ soils tested by Marschner et al. [62]; ${ }^{\dagger}$ Smith, et al. [68].

data can be noted for certain substrates, which reflects the highly heterogeneous nature of these substrates in terms of $\mathrm{Pb}$ form, particle size, etc. The bioaccessibility of three slag materials was evaluated at 17,20 , and 73\% [84]. Also, among mining site soils and urban topsoils, the IVBA was shown to vary from low (9-14\%) to high (63-75\%) [65].

\section{Pb speciation}

Speciation in the particles can be a strong indicator of the potential bioavailability of $\mathrm{Pb}$. Indeed, RBA estimates can vary widely (6-105\%) for $\mathrm{Pb}$ particles across the same site or region (e.g. California Gulch, CO), reflecting variability in their mineral composition and the potential of $\mathrm{Pb}$ to be liberated [42]. According to Schoof et al., the solubility of $\mathrm{Pb}$ minerals present in the test material explains the observed differences in bioavailability results [40]. In addition, Rasmussen et al. successfully predicted their bioaccessibility results on dust from 924 Canadian homes by identifying the $\mathrm{Pb}$ phases present with XANES, and further cumulating the bioaccessibility specific to each phase [124]. Identifying the major species present in a soil would therefore help in predicting the extent of bioavailability. Schoof et al. classified the 
range of solubility of $\mathrm{Pb}$ minerals as very high for $\mathrm{Pb}$ oxide $[\mathrm{PbO}]$; average for $\mathrm{Pb}$-manganese [ $\mathrm{Pb}-\mathrm{Mn}]$ oxides, $\mathrm{Pb}$-iron $[\mathrm{Pb}-\mathrm{Fe}]$ oxides, and $\mathrm{Pb}$ carbonates; moderate for $\mathrm{Pb}$ sulfates and $\mathrm{Pb}$ arsenate; and minimal for $\mathrm{Pb}$ phosphates $[\mathrm{Pb}-\mathrm{P}]$ [40]. The reference USEPA classification for bioavailability (and therefore bioaccessibility) after several in vivo and in vitro studies varies from high for cerussite $\left[\mathrm{PbCO}_{3}\right]$ and $\mathrm{Pb}-\mathrm{Mn}$ oxide (> 75\%), to medium for $\mathrm{Pb}-\mathrm{P}$ and $\mathrm{PbO}(25-75 \%)$, to low for anglesite, galena, $\mathrm{Fe}-\mathrm{Pb}$ species and remaining $\mathrm{Pb}$-based oxides $(<25 \%)$ [43]. Drexler and Brattin observed the lowest bioaccessibility for substrates containing anglesite or galena as dominant $\mathrm{Pb}$ species $(6-21 \%)$ [84]. On the contrary, substrates with either $\mathrm{PbCO}_{3}$ or $\mathrm{MnOOH}$ as the dominant $\mathrm{Pb}$ mineral systematically presented a high bioaccessibility $(65-90 \%)$, in agreement with the data on juvenile swine. $\mathrm{Pb}$ carbonate species are easily soluble, and this is reflected in other in vitro results: $\mathrm{Pb}$ carbonates were estimated to be $97 \%$ bioaccessible in the Schaider et al. study [108]; hydrocerussite paint $69 \%$ bioaccessible prior to cola addition in another study [93]; and $\mathrm{Pb}$ was $56 \%$ (gastric) and 25\% (intestinal) bioaccessible in the high carbonate garden soil G1 in the Denys et al. study [96].

Soil remediation with phosphates has been shown to decrease $\mathrm{Pb}$ bioaccessibility, in agreement with the expected low solubility of Pb-phosphate particles [114,118,120,135]. Nonetheless, a low bioavailability/bioaccessibility fraction should not be interpreted as representing a low hazard potential. Indeed, in the Schroder et al. study [70], the bioavailability of $\mathrm{Pb}$ in the Pb-rich soil $9(10,600 \mathrm{mg} \mathrm{Pb} / \mathrm{kg}$ soil) is medium to low (RBA 20\%, ABA 10\%), but a dose of $100 \mathrm{mg}$ of soil ingested daily will release the same quantity in the body, about $0.1 \mathrm{mg}$ of $\mathrm{Pb}$, like the highly $\mathrm{Pb}$ bioavailable but less Pb-rich soil 15 (RBA 74\%, ABA $37 \%$, $3230 \mathrm{mg} \mathrm{Pb} / \mathrm{kg}$ soil) (authors' calculation). Another facet of speciation concerns the major impact of the rate of $\mathrm{pH}$ change on the solution and mineralogical composition found at a given $\mathrm{pH}$. Marked differences in solubility were shown between tests conducted in dynamic versus static $\mathrm{pH}$ adjustment conditions for a soil dominated by cerussite and modified with hydroxyapatite [135]. The differences reached up to three orders of magnitude in the presence of phosphates, and were attributed to the mechanisms that govern the amount of soluble $\mathrm{Pb}$, with adsorption/desorption phenomena decreasing the amount of soluble $\mathrm{Pb}$ in dynamic systems.

\section{Particle size}

It is generally accepted that a small particle size provides a high surface to volume ratio and an elevated potential for dissolution [69]. Indeed, Casteel et al. found a high RBA (57-58\%) for soils of $\leq 250 \mu \mathrm{m}$ containing a majority of particles $\leq 10 \mu \mathrm{m}$ [49]. The significant BLLs observed in piglets dosed with "predicted low bioavailable" tailings were partly explained by the small size of the galena crystals (mostly $<10 \mu \mathrm{m}$ ) that were completely dissolved within $50-100 \mathrm{~min}$ at a low gastric $\mathrm{pH}$ [79]. Rieuwerts et al. reported a bioaccessibility of about $61-116 \%$ for particles $<64 \mu \mathrm{m}$, while particles $>64 \mu \mathrm{m}$ were 21 to $72 \%$ bioaccessible [117]. Mercier et al. showed that $\mathrm{Pb}$ bioaccessibility generally decreased with increasing granulometry $(<63 \mu \mathrm{m}$ to $125-250 \mu \mathrm{m})$, but remained stable or varied without any trend between $125-250 \mu \mathrm{m}$ and $<2 \mathrm{~mm}$, depending on the substrate [119]. Yu et al. [113] did not find any significant differences in the bioaccessibility estimates between the dust size fractions $<75 \mu \mathrm{m}, 75-150 \mu \mathrm{m}$, and $150-250 \mu \mathrm{m}$, and, finally, Morman et al. [109] found similar ranges for soil particles $<2 \mathrm{~mm}(8.5-77 \%)$ as compared to particles $<250 \mu \mathrm{m}$ (3.7-45\%), suggesting that small particles are not always more bioaccessible. Such differences may be partly explained by the $\mathrm{Pb}$ phase of the particles tested: less soluble $\mathrm{Pb}$ phases (anglesite, pyromorphite, and galena) were more influenced by particle size than the more soluble $\mathrm{Pb}$ phases in the Medlin study [88], bioaccessibility increasing about 4- to 13-fold between the fractions $<38 \mu \mathrm{m}$ and $<250-125 \mu \mathrm{m}$. Moreover, Ruby et al. showed that $\mathrm{Pb}$ dissolution rates are not affected by particle size, except for diameters less than $2.4 \mu \mathrm{m}$ [81]. Finally, Oliver et al. noted that greater bioaccessibility for small particles is more evident for equivalent diameters below $100 \mu \mathrm{m}$, so the impact of particle size on bioaccessibility results would only be significant for very small and colloidal particles [89].

For a given test material, an increase in bioaccessibility/bioavailability that is in inverse proportion to particle size may reflect a relative enrichment in smaller size fractions. Indeed, Juhasz et al. report up to five times more $\mathrm{Pb}$ in the $<50 \mu \mathrm{m}$ particle size fraction of sixteen peri-urban soils [136]. Also noted were significant increases in gastric-SBRC IVBA for six of those soils, but no differences in intestinal-SBRC IVBA between the size fractions. Madrid et al. observed a higher $\mathrm{Pb}$ content in the clay fraction $(<2 \mu \mathrm{m})$ of urban soils from Sevilla, as well as an increase in the bioaccessible $\mathrm{Pb}$ in this size fraction [137]. Finally, a $110 \%$ average $\mathrm{Pb}$ enrichment was measured in the particle size fraction adhering to hands for different types of soils in Canada, as compared to the bulk $\mathrm{Pb}$ content [138]. As the fraction adhering to hands is usually smaller than the $<250 \mu \mathrm{m}$ particle size fraction traditionally used for soils, these authors recommend conducting bioaccessibility experiments on small particles, for example $<45 \mu \mathrm{m}$.

\section{Matrix characteristics}

The characteristics of the matrix surrounding $\mathrm{Pb}$ can also influence $\mathrm{Pb}$ release for a given type of particle. $\mathrm{Pb}$ bioaccessibility has been related to total $\mathrm{Pb}$ content in 
soils, but also to other metal levels in the soils tested, such as zinc, iron, and cadmium [133,139]. Strongly positive linear relationships were found between $\mathrm{Pb}$ bioaccessibility and $\mathrm{Pb}$ content in the soils [133]. It can be expected that a higher $\mathrm{Pb}$ content will result in greater bioaccessibility. However, Morman et al. found no correlation between total elemental content $(\mathrm{Pb}, \mathrm{Cd}$, $\mathrm{Ni}, \mathrm{Cr}$, and As) and the bioaccessible fraction for the twenty soils from various sources [109]. Comparable RBA results (56-58\%) were obtained with Aspen Berm and residential soils of comparable particle size, matrix, and mineral type, although the Berm soil contained four times as much $\mathrm{Pb}$ [49]. Oomen et al. also found higher bioaccessibility for Flanders sandy loam (91\%) than for Oker 11 sandy loam (56\%), although the latter contained ten times more $\mathrm{Pb}$ [82]. This indicates that bioavailability is more influenced by the particle type distribution than by its $\mathrm{Pb}$ content.

Bioaccessible $\mathrm{Pb}$ was related to other characteristics of the soil matrix than total metal content, such as carbonates, clay, and organic matter, in soils from similar sources $[133,140]$. However, another study did not find a significant relationship between $\mathrm{Pb}$ bioaccessibility and the total amount of carbonates in a variety of high $\mathrm{Pb}$ carbonate soils [96]. Caboche et al. found significant correlation to the cation exchange capacity; organic matter; and clay, manganese, phosphorus, and iron content for soils from the same source. However, no correlations were found when soils from all the sources tested were pooled [134]. In addition, the bioaccessibility of twenty soils from various sources in another study was not correlated to the organic carbon, $\mathrm{pH}$, and clay percentage in the soils [109]. These findings suggest that significant relationships with soil characteristics can be found for soils from the same source type, but that they cannot be generalized to other matrices.

Overall, soil characteristics will impact $\mathrm{Pb}$ bioaccessibility differently, depending on the $\mathrm{Pb}$ species present, and cannot be used as a general predictor of bioaccessibility, while $\mathrm{Pb}$ speciation may be more predictive of bioaccessibility.

\section{Gaps in bioaccessibility data}

This review documented an abundance of peer-reviewed studies on in vitro testing, on topics ranging from simple leaching procedures to validated procedures calibrated to in vivo animal studies, and their application to a range of $\mathrm{Pb}$ bearing substrates. Among all the methods developed to estimate $\mathrm{Pb}$ bioaccessibility, only a few have been successfully compared with in vivo data (Table 4), and only the RBALP has been calibrated, validated, and fully standardized [84]. Other procedures, such as UBM, RIVM, and SBRC, have been highly correlated to in vivo data, and sometimes nearly fully validated (UBM), and so their results can also be considered valid for improving exposure assessment and public health protection. However, additional validation with statistical analysis and round robin testing will be needed to standardize these procedures.

A significant number of substrates were tested using these validated procedures (Table 7). However, few data (one) are available on bioaccessibility on dust, although dust $\mathrm{Pb}$ content was evaluated at some of the sites studied. Also, only one paint substrate was tested and the NIST material used may not necessarily be representative of paint chips to which children are exposed. However, paint containing $\mathrm{Pb}$ is not unusual in toys and old buildings [141], and recent results on paint chips using $\mathrm{HCl}$ extraction show high variability of leachable $\mathrm{Pb}$, ranging from 4 to $100 \%$ [122]. As well, some $\mathrm{HCl}$ extractions performed on dust particles have shown that the amount of leachable $\mathrm{Pb}$ is generally high [126], and this is partly attributed to the small size of these particles. $\mathrm{Pb}$ dust and $\mathrm{Pb}$ paint have been shown to be major contributors to the BLLs of children [142]. Further research is needed to quantify the variability in bioaccessibility for these particles, to support the estimation of the contribution of paint and dust particles to exposure, and to help analyze the reported pica-caused BLL cases associated with ingestion of these particles. There is also a significant data gap regarding $\mathrm{Pb}$ particles from drinking water systems. Early results using the RBALP adapted for $\mathrm{Pb}$ particles from tap water show that the bioaccessibility of particles generated from plumbing metals and collected from distribution systems varies widely [29]. Such data are needed, considering that: (i) particulate $\mathrm{Pb}$ can be sporadically high and is currently not fully considered in drinking water sampling and analysis methods; (ii) baby bottles may be prepared with tap water; and (iii) tap water $\mathrm{Pb}$ particles and colloids are small and may be highly soluble, depending on the forms present $[26,27,143]$.

Finally, most of the bioaccessibility results were measured in a fasting state, which is considered to be the worst case ingestion scenario. This ingestion state may be realistic for soil, paint, and dust particles, but not for tap water $\mathrm{Pb}$ particles, which can be ingested in either the fasting or the fed state. The oral bioavailability of $\mathrm{Pb}$ in food cooked or prepared with high $\mathrm{Pb}$ particulate water might also be a relevant route of exposure to study [26]. However, the development and validation of a standardized in vitro test for a fed state would certainly be a challenge, considering the variability of food that can be ingested by children (other than milk) and the divergent results observed for several types of food [88]. The most disturbing finding is that higher bioaccessibility values are found for in vitro tests performed with whole milk powder than for those simulating a fasting state $[62,87]$. 
In fact, early studies show that milk consumption increases the absorption of PbAc in rats [144]. This has also been observed for hydrophobic organic compounds, and can be explained by the formation of soluble metal complexes with milk constituents $[86,106]$. Such information may not have been considered in the past because the major sources of $\mathrm{Pb}$ exposure were air and soil, and $\mathrm{Pb}$ exposure from these sources is not likely to occur at the same time as milk ingestion. However, considering that water is now established as a significant residual source of $\mathrm{Pb}$ exposure and that baby bottles are often prepared with tap water, the ingestion of formula made in this way probably constitutes the worst case exposure, as it involves both the dissolved and the particulate $\mathrm{Pb}$ in tap water. Therefore, it is not clear that in vitro procedures in a fasting state will provide worst case assessments of exposure for bottle-fed infants/children. One in vivo study was performed with the simultaneous dosage of soil and milk powder on juvenile swine [62]. However, the dosage of soil was not tested on its own, precluding any comparison between $\mathrm{Pb}$ absorption from soil particles alone and $\mathrm{Pb}$ absorption from particles in the presence of milk. The apparent increase in $\mathrm{Pb}$ bioavailability when $\mathrm{Pb}$ is ingested with milk certainly needs to be confirmed with an in vivo test on piglets, to compare both soluble and particulate $\mathrm{Pb}$ ingestion, with and without milk.

\section{Conclusion}

In vivo experiments on $\mathrm{Pb}$ particles have been carried out using animal models on a wide range of particulate $\mathrm{Pb}$ forms, mostly from contaminated soils. It is established that there are substantial anatomical and physiological differences between animal species and humans, especially children. The scarcity of data providing a direct estimate of the human absorption of $\mathrm{Pb}$ particles is a significant limitation on our ability to estimate bioavailability, a shortcoming that is partially addressed by the use of the most representative animal model. Of all the animal models evaluated, juvenile swine are considered the most appropriate animal model for human exposure studies. However, results from animal models should always be considered with caution when extrapolated to humans or used to validate results from in vitro testing. Critical factors to consider in order to ensure relevance to public health decision making include: (1) the limitations and specific features of the animal model; (2) targeting the human population in the design of animal studies, specifically the appropriate developmental stage; and (3) the use of plausible environmental doses and $\mathrm{Pb}$ speciation.

Results reporting $\mathrm{Pb}$ bioaccessibility reflect the experimental conditions considered, and, in the absence of a standard procedure, cannot be compared. At the same time, this variability is inextricably linked to the natural variability of human exposure to $\mathrm{Pb}$ particulates. The RBALP procedure seems well suited to $\mathrm{Pb}$ particles, since its results for gastric extraction can be successfully correlated to in vivo data on piglets. This test was completely validated and submitted to a rigorous QA/QC protocol. The addition of an intestinal bioaccessibility phase to better mimic $\mathrm{Pb}$ solubility at the neutral $\mathrm{pH}$ of absorption (UBM, SBRC, RIVM) may refine the bioavailability estimates. However, these tests are more costly than the RBALP and quite tedious, and the full validation of the tests simulating an intestinal phase is likely to be extremely challenging. The "stomach" UBM, which is in the process to be fully validated, appears to be a reliable test, and offers the major advantage of estimating the RBA of two other elements as well as $\mathrm{Pb}$ (arsenic and cadmium).

Finally, the validated tests were applied on a significant number of substrates, but mostly soils. The selection does not cover the whole variety of possible matrices surrounding $\mathrm{Pb}$ in environmental sources and other significant sources of exposure, such as those of paint, as well as dust and tap water. Testing these types of particles in vitro raises experimental challenges, because of their heterogeneity and the small amounts of some of them, but is needed to complete the input in exposure models and risk assessment studies. The RBALP could be adapted for estimating bioaccessibility from these sources, since this test is quite simple to perform compared to other procedures, and presents the highest degree of standardization.

Competing interests

The authors declare they have no competing interests.

\section{Authors' contribution}

ED and MP carried out the literature research for the review and drafted the manuscript. RT, ME, and SS reviewed and completed the manuscript. All authors read and approved the final manuscript.

\section{Acknowledgments}

The authors acknowledge funding from the Canadian Water Network, the Natural Sciences and Engineering Research Council (NSERC) and the Canada Industrial Chair on Drinking Water partners, namely the City of Montreal, Ville Laval, and JMI-Veolia.

\section{Author details}

${ }^{1}$ Civil, Geological, and Mining Engineering Department, NSERC Industrial Chair on Drinking Water, Ecole Polytechnique de Montréal, CP 6079, Succ. Centre-Ville, Montréal, QC H3C 3A7, Canada. 'Environmental Health and Occupational Health Department, ESPUM (École de Santé Publique de I'Université de Montréal), C.P. 6128, succ. Centre-ville, Montréal, QC H3C 3J7, Canada. ${ }^{3}$ Department of Civil and Environmental Engineering, Virginia Tech University, 418 Durham Hall, Blacksburg, VA 24061, USA. ${ }^{\text {Department of }}$ Chemistry, Université de Montréal, 2900, Édouard-Montpetit, Montréal, QC H3C 3A7, Canada.

Received: 20 September 2012 Accepted: 13 November 2012

Published: 22 November 2012 


\section{References}

1. Counter SA, Buchanan LH, Ortega F: Neurophysiologic and neurocognitive case profiles of andean patients with chronic environmental lead poisoning. J Toxicol Environ Health A 2009, 72:1150-1159.

2. Lamadrid-Figueroa H, Tellez-Rojo MM, Hernandez-Cadena L, Mercado-Garcia A, Smith D, Solano-Gonzalez M, Hernandez-Avila M, Hu H: Biological markers of fetal lead exposure at each stage of pregnancy. J Toxicol Environ Health A 2006, 69:1781-1796.

3. Needleman H: Lead poisoning. Annu Rev Med 2004, 55:209-222.

4. Needleman HL, Landrigan PJ: The health effects of low level exposure to lead. Annu Rev Publ Health 1981, 2:277-298.

5. Canfield RL, Henderson CR Jr, Cory-Slechta DA, Cox C, Jusko TA, Lanphear BP: Intellectual impairment in children with blood lead concentrations below 10 microg per deciliter. New Engl J Med 2003, 348:1517-1526.

6. Jusko TA, Henderson CR Jr, Lanphear BP, Cory-Slechta DA, Parsons PJ, Canfield RL: Blood lead concentrations < 10 microg/dL and child intelligence at 6 years of age. Environ Health Perspect 2008, 116:243-248.

7. Lanphear BP, Hornung R, Khoury J, Yolton K, Baghurst P, Bellinger DC, Canfield RL, Dietrich KN, Bornschein R, Greene T, Rothenberg SJ, Needleman HL, Schnaas L, Wasserman G, Graziano J, Roberts R: Low-level environmental lead exposure and children's intellectual function: an international pooled analysis. Environ Health Perspect 2005, 113:894-899.

8. Surkan PJ, Zhang A, Trachtenberg F, Daniel DB, McKinlay S, Bellinger DC: Neuropsychological function in children with blood lead levels $<10 \mathrm{ug} / \mathrm{dL}$. NeuroToxicology 2007, 28:1170-1177.

9. European Food Safety Authority (EFSA): EFSA panel on contaminants in the food chain (CONTAM), Scientific opition on lead in food. EFSA Journal 2010, 8:1-147.

10. Commission E: Opinion on voluntary risk assessment report on lead and lead compounds. Brussels, Belgium: Scientific Committee on Health and Environmental Risks SCHER; 2009

11. CDC: $C D C$ Response to advisory on childhood lead poisoning prevention Recommendations in "Low level lead exposure harms children: a renewed call of primary prevention"; 2012. http://www.nchh.org/Portals/0/Contents/ CDC_Response_Lead_Exposure_Recs.pdf.

12. Iabal S, Muntner P, Batuman V, Rabito FA: Estimated burden of blood lead levels $\geq 5 \mathrm{ug} / \mathrm{dl}$ in 1999-2002 and declines from 1988 to 1994 . Environ Res 2008, 107:305-311.

13. Pirkle JL, Kaufmann RB, Brody DJ, Hickman T, Gunter E, Paschal DC: Exposure of the U.S. population to lead, 1991-1994. Environ Health Perspect 1998, 106:745-750

14. United States Environmental Protection Agency (USEPA): Air quality criteria for lead (Volume I of II) Final report. Washington, DC, USA: United States Environmental Protection Agency (USEPA); 2006. Report No.: EPA 600/R-05144aF-bF.

15. United States Environmental Protection Agency (USEPA): Air quality criteria for lead (Volume I of II. Washington, DC, USA: United States Environmental Protection Agency (USEPA); 2006.

16. von Lindern I, Spalinger S, Petroysan V, Von Braun MC: Assessing remedial effectiveness through the blood lead:soil/dust lead relationship at the Bunker Hill Superfund Site in the Silver Valley of Idaho. Sci Total Environ 2003, 303:139-170.

17. von Lindern IH, Spalinger SM, Bero BN, Petrosyan V, Von Braun MC: The influence of soil remediation on lead in house dust. Sci Total Environ 2003, 303:59-78

18. Gulson B: Stable lead isotopes in environmental health with emphasis on human investigations. Sci Total Environ 2008, 400:75-92.

19. Lanphear BP, Burgoon DA, Rust SW, Eberly S, Galke W: Environmental exposures to lead and urban children's blood lead levels. Environ Res 1998, 76:120-130.

20. Lorenzana RM, Troast R, Mastriano M, Follansbee MH, Diamond GL: Lead intervention and pediatric blood lead levels at hazardous waste sites. J Toxicol Environ Health A 2003, 66:871-893.

21. Ranft $U$, Delschen $T$, Machtolf $M$, Sugiri $D$, Wilhelm M: Lead concentration in the blood of children and its association with lead in soil and ambient air - Trends between 1983 and 2000 in Duisburg. J Toxicol Environ Health A 2008, 71:710-715.

22. Lanphear BP, Hornung R, Ho M, Howard CR, Eberle S, Knauf K: Environmental lead exposure during early childhood. J Pediatr 2002, 140:40-47.

23. Brown MJ, Raymond J, Homa D, Kennedy C, Sinks T: Association between children's blood lead levels, lead service lines, and water disinfection, Washington, DC, 1998-2006. Environ Res 2011, 111:67-74.
24. Edwards M, Triantafyllidou S, Best D: Elevated blood lead levels in young children due to lead-contaminated drinking water: Washington: DC, 2001-2004. Envir Sci Technol 2009, 43:1618-1623.

25. Miranda ML, Kim D, Hull AP, Paul CJ, Galeano MAO: Changes in blood lead levels associated with use of chloramines in water treatment systems. Environ Health Perspect 2007, 115:221-225

26. Triantafyllidou S, Parks J, Edwards M: Lead particles in potable water. J Am Water Works Assoc 2007, 99:107-117.

27. Deshommes E, Laroche L, Nour S, Cartier C, Prévost M: Source and occurrence of particulate lead in tap water. Water Res 2010, 44:3734-3744

28. Deshommes E, Nour S, Richer B, Cartier C, Prévost M: POU devices in large buildings: Lead removal and water quality. J Am Water Works Assoc 2012, 104:E282-E297.

29. Deshommes E, Prévost $\mathrm{M}: \mathrm{Pb}$ particles from tap water: bioaccessibility and contribution to child exposure. Envir Sci Technol 2012, 46:6269-6277.

30. Mushak P: Gastro-intestinal absorption of lead in children and adults: overview of biological and biophysico-chemical aspects. Chem Spec Bioavail 1991, 3:87-104.

31. Needleman $\mathrm{HL}$, Bellinger $\mathrm{D}$ : The health-effects of low-level exposure to lead. Annu Rev Publ Health 1991, 12:111-140.

32. Wright DA, Welbourn P: Environmental Toxicology. Cambridge, UK: Cambridge University Press; 2002.

33. National Academy of Sciences/National Research Council (NAS/NRC): Bioavailability of contaminants in soils and sediments: processes, tools, and applications. Washington, DC, USA: National Academ Press; 2002.

34. Heath LM, Soole KL, McLaughlin ML, McEwan GT, Edwards JW: Toxicity of environmental lead and the influence of intestinal absorption in children. Rev Environ Health 2003, 18:231-250.

35. James HM, Hilburn ME, Blair JA: Effects of meals and meal times on uptake of lead from the gastrointestinal tract in humans. Hum Toxicol 1985, 4:401-407.

36. Rabinowitz MB, Kopple JD, Wetherill GW: Effect of food intake and fasting on gastrointestinal lead absorption in humans. Am J Clin Nutr 1980, 33:1784-1788

37. Ziegler EE, Edwards BB, Jensen RL, Mahaffey KR, Fomon SJ: Absorption and retention of lead by infants. Pediatr Res 1978, 12:29-34.

38. Maddaloni M, Lolacono N, Manton W, Blum C, Drexler J, Graziano J: Bioavailability of soilborne lead in adults, by stable isotope dilution. Environ Health Perspect 1998, 106:1589-1594.

39. Freeman GB, Johnson JD, Liao SC, Feder Pl, Davis AO, Ruby MV, Schoof RA, Chaney RL, Bergstrom PD: Absolute bioavailability of lead acetate and mining waste lead in rats. Toxicology 1994, 91:151-163.

40. Schoof RA, Butcher MK, Sellstone C, Ball RW, Fricke JR, Keller V, Keehn B: An assessment of lead absorption from soil affected by smelter emissions. Environ Geochem Health 1995, 17:189-199.

41. Weis CP, Poppenga RH, Thacker BJ, Henningsen GM, Curtis A: Design of pharmacokinetic and bioavailability studies of lead in an immature swine model, Proceedings of the Lead in Paint, Soil, and Dust: Health Risks, Exposure Studies, Control Measures, Measurement Methods, and Quality Assurance. 1994:3-11.

42. Casteel SW, Weis CP, Henningsen GM, Brattin WJ: Estimation of relative bioavailability of lead in soil and soil-like materials using young Swine. Environ Health Perspect 2006, 114:1162-1171.

43. United States Environmental Protection Agency (USEPA): Estimation of relative bioavailability of lead in soil and soil-like materials using in vivo and in vitro methods. Washington, DC, USA: Office of Solid Waste and Emergency Response; 2007. Report No.: OSWER 9285.7-77.

44. Freeman GB, Dill JA, Johnson JD, Kurtz PJ, Parham F, Matthews HB: Comparative absorption of lead from contaminated soil and lead salts by weanling Fischer 344 rats. Fund App/ Toxicol 1996, 33:109-119.

45. Freeman GB, Johnson JD, Killinger JM, Liao SC, Feder PI, Davis AO, Ruby MV, Chaney RL, Lovre SC, Bergstrom PD: Relative bioavailability of lead from mining waste soil in rats. Fund Appl Toxicol 1992, 19:388-398.

46. Smith DM Jr, Mielke HW, Heneghan JB: Subchronic lead feeding study in male rats and micropigs. Environ Toxicol 2008, 24:453-461.

47. Smith DM Jr, Mielke HW, Heneghan JB: Subchronic lead feeding study in male rats. Arch Environ Contam Toxicol 2008, 55:518-528.

48. Weis $C P$, LaVelle JM: Characteristics to consider when choosing an animal model for the study of lead bioavailability. Chem Spec Bioavail 1991, 3:113-119.

49. Casteel SW, Cowart RP, Weis CP, Henningsen GM, Hoffman E, Brattin WJ, Guzman RE, Starost MF, Payne JT, Stockham SL, Becker SV, Drexler JW, Turk 
JR: Bioavailability of lead to juvenile swine dosed with soil from the Smuggler Mountain NPL Site of Aspen, Colorado. Fund App/ Toxicol 1997, 36:177-187

50. Schoof RA: Guide for Incorporating bioavailability adjustments into human health and ecological risk assessments at US department of defense facilities. Part 1: overview of metals bioavailability. Battelle, Columbus, Ohio, USA: Naval Facilities Engineering Service Center Air Force Center for Environmental Excellence Army Environmental Center; 2003. Report No: OMB No. 0704-0811.

51. Polak J, O'Flaherty EJ, Freeman GB, Johnson JD, Liao SC, Bergstrom PD: Evaluating lead bioavailability data by means of a physiologically based lead kinetic model. Fund Appl Toxicol 1996, 29:63-70.

52. Mushak P: Uses and limits of empirical data in measuring and modeling human lead exposure. Environ Health Perspect 1998, 106:1467-1484.

53. Dieter MP, Matthews HB, Jeffcoat RA, Moseman RF: Comparison of lead bioavailability in F344 rats fed lead acetate, lead-oxide, lead sulfide, or lead ore concentrate from Skagway, Alaska. J Toxicol Environ Health 1993, 39:79-93.

54. Freeman GB, Liao SC, Feder PI, Trigg NJ, Johnson JD: Absolute bioavailability of lead following dosed feed mine waste administration in Sprague-Dawley rats. Battelle: Atlantic Richfield Company; 1993.

55. Ruby MV, Davis A, Link TE, Schoof R, Chaney RL, Freeman GB, Bergstrom $P$ : Development of an in vitro screening test to evaluate the in vivo bioaccessibility of ingested mine-waste lead. Envir Sci Technol 1993, 27:2870-2877

56. Lorenzana RM, Duncan B, Ketterer M, Lowry J, Simon J, Dawson M, Poppenga R: Bioavailability of arsenic and lead in environmental substrates. Washington, DC, USA: United States Environmental Protection Agency (USEPA); 1996

57. Ellickson KM, Meeker RJ, Gallo MA, Buckley BT, Lioy PJ: Oral bioavailability of lead and arsenic from a NIST standard reference soil material. Arch Environ Contam Toxicol 2001, 40:128-135.

58. Brown S, Chaney RL, Hallfrisch JG, Xue Q: Effect of biosolids processing on lead bioavailability in an urban soil. J Environ Qual 2003, 32:100-108.

59. Hettiarachchi GM, Pierzynski GM, Oehme FW, Sonmez O, Ryan JA: Treatment of contaminated soil with phosphorus and manganese oxide reduces lead absorption by Sprague-Dawley rats. J Environ Qual 2003, 32:1335-1345

60. United States Environmental Protection Agency (USEPA): Remedial investigation residential yard soil. Omaha lead site. Washington, DC, USA: Black and Veatch Special Projects Corporation; 2004. Report No.: 46130.

61. United States Environmental Protection Agency (USEPA): Omaha lead site (Final remedial investigation report) Volume 1. Omaha, Nebraska: Black and Veatch Special Projects Corporation; 2009.

62. Marschner B, Welge P, Hack A, Wittsiepe J, Wilhelm M: Comparison of soil $\mathrm{Pb}$ in vitro bioaccessibility and in vivo bioavailability with $\mathrm{Pb}$ pools from a sequential soil extraction. Envir Sci Technol 2006, 40:2812-2818.

63. MSE Technology Application I: Regional applied research effort (rare) project: interim report for investigation of changes in lead relative bioavailability following weathering of ore concentration-soil mixtures from the Herculaneum, Missouri, Smelter site. Butte, Montana, USA; 2006.

64. Bannon DI, Drexler JW, Fent GM, Casteel SW, Hunter PJ, Brattin WJ, Major MA: Evaluation of small arms range soils for metal contamination and lead bioavailability. Envir Sci Technol 2009, 43:9071-9076.

65. Caboche J: Validation d'un test de mesure de bioaccessibilité - application à 4 éléments traces métalliques dans les sols: $\mathrm{As}, \mathrm{Cd}$, Pb et Sb (Thèse). Institut National Polytechnique de Lorraine, Ecole Doctorale Ressources: Procédés, Produits et Environnemen; 2009.

66. Denys S, Caboche J, Tack K, Rychen G, Wragg J, Cave M, Jondreville C, Feidt C: In Vivo Validation of the Unified BARGE Method to Assess the Bioaccessibility of Arsenic, Antimony, Cadmium, and Lead in Soils. Envir Sci Technol 2012, 46:6252-6260.

67. Juhasz AL, Weber J, Smith E, Naidu R, Marschner B, Rees M, Rofe A, Kuchel $T$, Sansom L: Evaluation of SBRC-gastric and SBRC-intestinal methods for the prediction of in vivo relative lead bioavailability in contaminated soils. Envir Sci Technol 2009, 43:4503-4509.

68. Smith E, Kempson IM, Juhasz AL, Weber J, Rofe A, Gancarz D, Naidu R, McLaren RG, Gräfe M: In vivo-in vitro and XANES spectroscopy assessments of lead bioavailability in contaminated periurban soils. Envir Sci Technol 2011, 45:6145-6152.

69. Ruby MV, Schoof R, Brattin W, Goldade M, Post G, Harnois M, Mosby DE, Casteel SW, Berti W, Carpenter M, Edwards D, Cragin D, Chappell W:
Advances in evaluating the oral bioavailability of inorganics in soil for use in human health risk assessment. Envir Sci Technol 1999, 33:3697-3705

70. Schroder JL, Basta NT, Casteel SW, Evans TJ, Payton ME, Si J: Validation of the in vitro gastrointestinal (IVG) method to estimate relative bioavailable lead in contaminated soils. J Environ Qual 2004, 33:513-521.

71. Battelle: Absolute bioavailability of lead following dose feed mine waste administration in Sprague-Dawley rats. Columbus, Ohio, USA: Battelle Columbus Operations; 1993.

72. PTI Environmental Services: Bioavailability study remedial investigation report. National Zinc Site (Volume 1), Appendix N. City of Bartlesville, Oklahoma, USA: Cyprus Amax Minerals Company, and Salomon, Inc; 1994

73. PTI Environmental Services: Remedial investigation report. National Zinc Site (Volume 1). City of Bartlesville, Oklahoma, USA: Cyprus Amax Minerals Company, and Salomon, Inc; 1994

74. Ruby MV, Davis A, School R, Eberle S, Sellstone CM: Estimation of lead and arsenic bioavailability using a physiologically based extraction test. Envir Sci Technol 1996, 30:422-430

75. McConnell EL, Basit AW, Murdan S: Measurements of rat and mouse gastrointestinal $\mathrm{pH}$ fluid and lymphoid tissue, and implications for in-vivo experiments. J Pharm Pharmacol 2008, 60:63-70.

76. Merchant HA, McConnell EL, Liu F, Ramaswamy C, Kulkarni RP, Basit AW, Murdan S: Assessment of gastrointestinal $\mathrm{pH}$, fluid and lymphoid tissue in the guinea pig, rabbit and pig, and implications for their use in drug development. Eur J Pharm Sci 2011, 42:3-10.

77. Huang FN, Schneider JS: Effects of lead exposure on proliferation and differentiation of neural stem cells derived from different regions of embryonic rats brain. NeuroToxicology 2004, 25:1001-1012.

78. Moughan PJ, Birtles MJ, Cranwell PD, Smith WC, Pedraza M: The piglet as a model animal for studying aspects of digestion and absorption in milk-fed human infants. World Rev Nutr Diet 1992, 67:40-113.

79. LaVelle JM, Poppenga RH, Thacker BJ, Giesy JP, Weis C, Othoudt R, Vandervoort C: Bioavailability of lead in mining waste: an oral intubation study in young swine. Chem Spec Bioavail 1991, 3:105-111.

80. Weis CP, Henningsen GM, Poppenga RH, Thacker BJ: Pharmacokinetics of lead in blood of immature swine following acute oral and intravenous exposure. Toxicologist 1993, 13:175

81. Ruby MV, Davis A, Kempton JH, Drexler JW, Bergstrom PD: Lead bioavailability: dissolution kinetics under simulated gastric conditions. Envir Sci Technol 1992, 26:1242-1248.

82. Oomen AG, Hack A, Minekus M, Zeijdner E, Cornelis C, Schoeters G, Verstraete W, Van De Wiele T, Wragg J, Rompelberg CJM, Sips AJAM, Van Wijnen $\mathrm{JH}$ : Comparison of five in vitro digestion models to study the bioaccessibility of soil contaminants. Envir Sci Technol 2002, 36:3326-3334.

83. Yang J-K, Barnett MO, Jardine PM, Brooks SC: Factors controlling the bioaccessibility of arsenic(V) and lead(II) in soil. Soil Sed Contam 2003, 12:165-179.

84. Drexler JW, Brattin WJ: An in vitro procedure for estimation of lead relative bioavailability: with validation. Hum Ecol Risk Assess 2007, 13:383-401

85. Oomen AG, Tolls J, Sips AJAM, Van Den Hoop MAGT: Lead speciation in artificial human digestive fluid. Arch Environ Contam Toxicol 2003, 44:107-115.

86. Oomen AG, Brandon EFA, Swartjes FA, Sips AJAM: How can information on oral bioavailability improve human health risk assessment for leadcontaminated soils? Implementation and scientific basis. Bilthoven, the Netherlands: Rijksinstituut voor Volksgezondheid en Milieu (RIVM); 2006. RIVM report No:: 711701042/2006

87. Van De Wiele TR, Oomen AG, Wragg J, Cave M, Minekus M, Hack A, Cornelis C, Rompelberg CJM, De Zwart LL, Klinck B, Van Wijnen J, Verstraete W, Sips AJAM: Comparison of five in vitro digestion models to in vivo experimental results: Lead bioaccessibility in the human gastrointestinal tract. J Environ Sci Heal A 2007, 42:1203-1211.

88. Medlin EA: An in vitro method for estimating the relative bioavailability of lead in humans (Masters). Boulder, Colorado, USA: University of Colorado; 1997.

89. Oliver DP, McLaughlin MJ, Naidu R, Smith LH, Maynard EJ, Calder IC: Measuring $\mathrm{Pb}$ bioavailability from household dusts using an in vitro model. Envir Sci Technol 1999, 33:4434-4439.

90. Oomen AG, Rompelberg CJM, Van De Kamp E, Pereboom DPKH, De Zwart LL, Sips AJAM: Effect of bile type on the bioaccessibility of soil contaminants in an in vitro digestion model. Arch Environ Contam Toxicol 2004, 46:183-188. 
91. Gasser UG, Walker WJ, Dahlgren RA, Borch RS, Burau RG: Lead release from smelter and mine waste impacted materials under simulated gastric conditions and relation to speciation. Envir Sci Technol 1996, 30:761-769.

92. Hamel SC, Buckley B, Lioy PJ: Bioaccessibility of metals in soils for different liquid to solid ratios in synthetic gastric fluid. Envir Sci Technol 1998, 32:358-362.

93. Scheckel KG, Ryan JA: In vitro formation of pyromorphite via reaction of Pb sources with soft-drink phosphoric acid. Sci Total Environ 2003, 302:253-265.

94. Bruce $\mathrm{S}$, Noller B, Matanitobua $\mathrm{V}, \mathrm{Ng} \mathrm{J}$ : In vitro physiologically based extraction test (PBET) and bioaccessibility of arsenic and lead from various mine waste materials. J Toxicol Environ Health A 2007. 70:1700-1711.

95. Wragg J, Cave M, Basta N, Brandon E, Casteel S, Denys S, Gron C, Oomen A, Reimer K, Tack K, Van de Wiele T: An inter-laboratory trial of the unified BARGE bioaccessibility method for arsenic, cadmium and lead in soil. Sci Total Environ 2011, 409:4016-4030

96. Denys S, Caboche J, Tack K, Delalain P: Bioaccessibility of lead in high carbonate soils. J Environ Sci Heal A 2007, 42:1331-1339.

97. Oomen AG, Tolls J, Sips AJ, Groten JP: In vitro intestinal lead uptake and transport in relation to speciation. Arch Environ Contam Toxicol 2003, 44:116-124.

98. Turner A, Simmonds L: Elemental concentrations and metal bioaccessibility in UK household dust. Sci Total Environ 2006, 371:74-81.

99. Weltje L, Den Hollander W, Wolterbeek HT: Adsorption of metals to membrane filters in view of their speciation in nutrient solution. Environ Toxicol Chem 2003, 22:265-271.

100. Dean JR, Ma R: Approaches to assess the oral bioaccessibility of persistent organic pollutants: a critical review. Chemosphere 2007, 68:1399-1407.

101. Brandon EFA, Oomen AG, Rompelberg CJM, Versantvoort CHM, Van Engelen JGM, Sips AJAM: Consumer product in vitro digestion model: bio accessibility of contaminants and its application in risk assessment. Regul Toxicol Pharmacol 2006, 44:161-171.

102. Hamel SC, Ellickson KM, Lioy PJ: The estimation of the bioaccessibility of heavy metals in soils using artificial biofluids by two novel methods: mass-balance and soil recapture. Sci Total Environ 1999, 243-244:273-283.

103. Ljung K, Oomen A, Duits M, Selinus O, Berglund M: Bioaccessibility of metals in urban playground soils. J Environ Sci Heal A 2007, 42:1241-1250.

104. Saikat S, Barnes B, Westwood D: A review of laboratory results for bioaccessibility values of arsenic, lead and nickel in contaminated UK soils. J Environ Sci Heal A 2007, 42:1213-1221.

105. Group ES: Bioavailability and Bioaccessibility of Inorganic Contaminants in Soil: Answering Key Questions, Proceedings of the BARC Workshop Proceedings. Bioaccessibility research Canada: BARC; 2011:175.

106. Hack A, Selenka F: Mobilization of PAH and PCB from contaminated soil using a digestive tract model. Toxicol Lett 1996, 88:199-210.

107. Bosso ST, Enzweiler J: Bioaccessible lead in soils, slag, and mine wastes from an abandoned mining district in Brazil. Environ Geochem Health 2008, 30:219-329.

108. Schaider LA, Senn DB, Brabander DJ, Mccarthy KD, Shine JP: Characterization of zinc, lead, and cadmium in mine waste: implications for transport, exposure, and bioavailability. Envir Sci Technol 2007, 41:4164-4171.

109. Morman SA, Plumlee GS, Smith DB: Application of in vitro extraction studies to evaluate element bioaccessibility in soils from a transect across the United States and Canada. App/ Geochem 2009, 24:1454-1463.

110. Ryan JA, Scheckel KG, Berti WR, Brown SL, Casteel SW, Chaney RL, Hallfrisch J, Doolan M, Grevatt P, Maddaloni M, Mosby DE: Reducing children's risk from lead in soil. Envir Sci Technol 2004, 38:18A-24A

111. Zia MH, Codling EE, Scheckel KG, Chaney RL: In vitro and in vivo approaches for the measurement of oral bioavailability of lead $(\mathrm{Pb})$ in contaminated soils: a review. Environ Pollut 2011, in press.

112. Smith E, Weber J, Naidu R, McLaren RG, Juhasz AL: Assessment of lead bioaccessibility in peri-urban contaminated soils. J Hazard Mater 2011, 186:300-305.

113. Yu CH, Yiin LM, Lioy PJ: The bioaccessibility of lead $(\mathrm{Pb})$ from vacuumed house dust on carpets in urban residences. Risk Anal 2006, 26:125-134.

114. Bosso ST, Enzweiler J, Angelica RS: Lead bioaccessibility in soil and mine wastes after immobilization with phosphate. Water Air Soil Poll 2008, 195:257-273.

115. Sialelli J, Urquhart GJ, Davidson CM, Hursthouse AS: Use of a physiologically based extraction test to estimate the human bioaccessibility of potentially toxic elements in urban soils from the city of Glasgow, UK. Environ Geochem Health 2010, 32:517-527.

116. Sheppard SC, Evenden WG, Schwartz WJ: Ingested soil: bioavailability of sorbed lead, cadmium, cesium, iodine, and mercury. J Environ Qual 1995, 24:498-505

117. Rieuwerts JS, Farago ME, Cikrt M, Bencko V: Differences in lead bioavailability between a smelting and a mining area. Water Air Soil Poll 2000, 122:203-229.

118. Yang J, Mosby DE, Casteel SW, Blanchar RW: Lead immobilization using phosphoric acid in a smelter-contaminated urban soil. Envir Sci Technol 2001, 35:3553-3559.

119. Mercier G, Duchesne J, Carles-Gibergues A: A new in vitro test to simulate gastric absorption of copper, lead, tin and zinc from polluted soils. Environ Technol 2002, 23:121-133.

120. Yang J, Mosby DE, Casteel SW, Blanchar RW: In vitro lead bioaccessibility and phosphate leaching as affected by surface application of phosphoric acid in lead-contaminated soil. Arch Environ Contam Toxicol 2002, 43:399-405.

121. Beak DG, Basta NT, Scheckel KG, Traina SJ: Bioaccessibility of lead sequestered to corundum and ferrihydrite in a simulated gastrointestinal system. J Environ Qual 2006, 35:2075-2083.

122. Le Bot B, Arcelin C, Briand E, Glorennec P: Sequential digestion for measuring leachable and total lead in the same sample of dust or paint chips by ICP-MS. J Environ Sci Heal A 2011, 46:63-69.

123. Le Bot B, Gilles E, Durand S, Glorennec P: Bioaccessible and quasi-total metals in soil and indoor dust. Eur J Mineral 2010, 22:651-657.

124. Rasmussen PE, Beauchemin S, Chenier M, Levesque C, MacLean LCW, Marro L, Jones-Otazo H, Petrovic S, McDonald LT, Gardner HD: Canadian house dust study: lead bioaccessibility and speciation. Envir Sci Technol 2011, 45:4959-4965.

125. Berti WR, Cunningham SD: In-place inactivation of $\mathrm{Pb}$ in $\mathrm{Pb}$ contaminated soils. Envir Sci Technol 1997, 31:1359-1364.

126. Davis A, Ruby MV, Goad P, Eberle S, Chryssoulis S: Mass balance on surface-bound, mineralogic, and total lead concentrations as related to industrial aggregate bioaccessibility. Envir Sci Technol 1997, 31:37-44

127. Turner A, Ip K-H: Bioaccessibility of metals in dust from the indoor environment: application of a physiologically based extraction test. Envir Sci Technol 2007, 41:7851-7856.

128. Turner A, Singh N, Richards JP: Bioaccessibility of metals in soils and dusts contaminated by marine antifouling paint particles. Environ Pollut 2009, 157:1526-1532.

129. Wragg J, Cave MR: In-vitro methods for the measurement of the oral bioaccessibility of selected metals and metalloids in soils: a critical review. Bristol, United Kingdom: British Geological Survey. Environment Agency; 2002. Report No.: P5-062/TR/01.

130. Chu M, Beauchemin D: Simple method to assess the maximum bioaccessibility of elements from food using flow injection and inductively coupled plasma mass spectrometry. J Anal Atom Spectrom 2004 19:1213-1216.

131. Jimoh M, Frenzel W, Müller V: Microanalytical flow-through method for assessment of the bioavailability of toxic metals in environmental samples. Anal Bioanal Chem 2005, 381:438-444.

132. Laird BD, Van De Wiele TR, Corriveau MC, Jamieson HE, Parsons MB, Verstraete W, Siciliano SD: Gastrointestinal microbes increase arsenic bioaccessibility of ingested mine tailings using the simulator of the human intestinal microbial ecosystem. Envir Sci Technol 2007, 41:5542-5547.

133. Roussel H, Waterlot C, Pelfrêne A, Pruvot C, Mazzuca M, Douay F: Cd, Pb and $\mathrm{Zn}$ oral bioaccessibility of urban soils contaminated in the past by atmospheric emissions from two lead and zinc smelters. Arch Environ Contam Toxicol 2010, 58:945-954.

134. Caboche J, Denys S, Feidt C, Delalain P, Tack K, Rychen G: Modelling Pb bioaccessibility in soils contaminated by mining and smelting activities. $J$ Environ Sci Heal A 2010, 45:1264-1274.

135. Zhang PC, Ryan JA, Yang J: In vitro soil Pb solubility in the presence of hydroxyapatite. Envir Sci Technol 1998, 32:2763-2768.

136. Juhasz AL, Weber J, Smith E: Impact of soil particle size and bioaccessibility on children and adult lead exposure in pen-urban contaminated soils. J Hazard Mater 2011, 186:1870-1879.

137. Madrid F, Diaz-Barrientos E, Madrid L: Availability and bio-accessibility of metals in the clay fraction of urban soils of Sevilla. Environ Pollut 2008, 156:605-610. 
138. Siciliano SD, James K, Zhang G, Schafer AN, Peak JD: Adhesion and enrichment of metals on human hands from contaminated soil at an arctic urban brownfield. Envir Sci Technol 2009, 43:6385-6390.

139. Pelfrêne A, Waterlot C, Mazzuca M, Nisse C, Bidar G, Douay F: Assessing Cd, $\mathrm{Pb}, \mathrm{Zn}$ human bioaccessibility in smelter-contaminated agricultural topsoils (northern France). Environ Geochem Health 2011, 22:477-493.

140. Poggio L, Vrscaj B, Schulin R, Hepperle E, Marsan FA: Metals pollution and human bioaccessibility of topsoils in Grugliasco (Italy). Environ Pollut 2009, 157:680-689.

141. Lead recalls: toys: Department of Health and Human Service; 2010. Accessed at http://www.cdc.gov/nceh/lead/Recalls/toys.htm.

142. Lanphear BP, Dietrich KN, Berger O: Prevention of lead toxicity in US children. Ambul Pediatr 2003, 3:27-36.

143. McNeill LS, Edwards M: Importance of $\mathrm{Pb}$ and Cu particulate species for corrosion control. J Environ Eng 2004, 130:136-144.

144. Bell RR, Spickett JT: The influence of milk in the diet on the toxicity of orally ingested lead in rats. Food Cosmet Toxicol 1981, 19:429-436.

Cite this article as: Deshommes et al:: Experimental determination of the oral bioavailability and bioaccessibility of lead particles. Chemistry Central Journal 2012 6:138.

\section{Publish with ChemistryCentral and every scientist can read your work free of charge \\ "Open access provides opportunities to our colleagues in other parts of the globe, by allowing anyone to view the content free of charge." \\ W. Jeffery Hurst, The Hershey Company. \\ - available free of charge to the entire scientific community \\ - peer reviewed and published immediately upon acceptance \\ - cited in PubMed and archived on PubMed Central \\ - yours - you keep the copyright \\ Submit your manuscript here: \\ http://www.chemistrycentral.com/manuscript/<smiles>c1ccccc1</smiles> 